\title{
JÁCARA CON VARIEDAD DE TONOS.* RELACIONES ENTRE TONOS HUMANOS Y MÚSICA TEATRAL EN EL SIGLO XVII
}

\author{
Mariano LAMBEA (CSIC) \\ Lola JOSA (Universidad de Barcelona)
}

\begin{abstract}
Resumen: El presente trabajo consiste en la edición de una Jácara con variedad de tonos que se conserva en la Biblioteca de Catalunya, y en su correspondiente estudio que se deriva del especial planteamiento poético-musical que requiere su complejidad textual (tanto poética como musical). Su anónimo autor la define como "Jacarilla al Nacimiento" y "ensalada burlesca", aunque en realidad se trata de una narración jocosa para poner de manifiesto el arte de ingenio barroco, a propósito (en este caso) de un acontecimiento capital en nuestra cultura. El argumento lírico de este extraordinario poema avanza mediante íncipits poéticomusicales de tonos humanos que gozaron de amplia popularidad y aprecio en el siglo XVII, mezclados con versos de inspiración propia, que, a lo divino, generan un juego entre el decir y el cantar; tonos pertenecientes tanto a ámbitos cortesanos (música vocal de cámara) como a contextos dramáticos (música para el teatro -comedias, entremeses, autos sacramentales- y música específicamente teatral-zarzuelas, fiestas cantadas, óperas-). De algunos de ellos no se conoce ninguna fuente, ni literaria ni musical; otros, en cambio, presentan concordancias muy interesantes. Por ello, en el trabajo se estudiarán los vínculos y los caminos de ida y vuelta entre ambos repertorios, para establecer las oportunas correspondencias, consignar las variantes y apreciar las citas intertextuales, especialmente musicales.
\end{abstract}

Palabras clave: Jácara (s. XVII). Tonos humanos (s. XVII). Música teatral (s. XVII). Intertextualidad musical

\section{Objetivo}

El objetivo del presente trabajo es, en primer lugar, facilitar la edición crítica de la Jácara con variedad de tonos; y, en segundo lugar, confrontar sus citas parciales de tonos famosos con las otras fuentes musicales que conocemos para establecer las oportunas confrontaciones y arrojar luz sobre los procesos de transmisión musical de este repertorio y las citas intertextuales que podamos detectar. Para las confrontaciones literarias (teatrales) remitimos a dos libros básicos sobre la música en nuestro teatro áureo: el de Stein ${ }^{1}$ y el de Flórez ${ }^{2}$, ya que el lector hallará en ellos cumplida referencia de las piezas dramáticas que contienen los tonos de la jácara; incluso encontrará referencias concretas sobre algunas fuentes musicales que nos eximen a nosotros de citarlas innecesariamente. Si embargo, la investigación avanza, como es lógico, con el paso del tiempo, y, en consecuencia, alguna referencia literaria, o incluso musical, que no conste en los trabajos de estas investigadoras, y que nosotros hayamos podido hallar, la detallaremos convenientemente.

\footnotetext{
* El presente trabajo se inscribe dentro del Grup de Recerca Consolidat 2009 SGR 973: «Aula Música Poética», financiado por la Generalitat de Catalunya.

${ }^{1}$ STEIN, Louise K. Songs of Mortals, Dialogues of the Gods. Music and Theatre in Seventeenthcentury Spain. Oxford: Clarendon Press, 1993.

${ }^{2}$ FlóReZ, María Asunción. Música teatral en el Madrid de los Austrias durante el Siglo de Oro. Madrid: ICCMU, 2006.
} 
Por otro lado, algunos tonos de la jácara no tienen fuente poética ni musical conocida hasta el presente, siendo pues una primicia que consten en este trabajo, circunstancia que demuestra la utilidad del mismo a los estudiosos de la filología y de la musicología, ahora y en el futuro, pues conforme se vayan realizando catálogos tan completos como el de la Biblioteca Nacional a cargo del equipo de Pablo Jauralde y se vayan digitalizando fondos documentales, irán apareciendo nuevas fuentes ${ }^{3}$. Y esto es válido también para la música como es obvio.

Confrontaremos entre sí las versiones musicales que nos parezcan más interesantes por sus variantes melódicas, rítmicas o armónicas. Cuando no nos haya sido posible consultar la fuente original utilizaremos la edición, o ediciones, modernas más fiables. En cualquier caso la inmensa mayoría de estas ediciones se relacionan en nuestro IPEM ${ }^{4}$.

\section{Introducción}

En la Biblioteca de Catalunya se conserva una composición anónima titulada Jácara con variedad de tonos para voz sola y guión instrumental ${ }^{5}$. El manuscrito, copiado pulcramente tanto en la música como en la letra, no tiene fecha pero todos los indicios apuntan a que pertenece a las últimas décadas del siglo XVII. Distinguimos dos copistas: uno para el texto poético (dos páginas) y para la parte vocal, también con texto (dos páginas más), y otro para el acompañamiento, también con las primeras palabras de los tonos (una página).

Esta original obra poético-musical ofrece la particularidad de estar compuesta por veintiún fragmentos, en realidad, íncipits de tonos que, en su día, gozaron de amplia difusión. Cada uno de los íncipits consta de dos versos con su música a los que se añaden otros dos más, sin música, simplemente declamados o recitados. Las estrofas resultantes son cuartetas engarzadas que progresan conformando una llamativa argumentación en torno al Nacimiento, ya que el autor tomó los dos primeros versos de tonos que se cantaban en la corte y en el teatro, y los complementó con otros versos suyos que confiere una significación alusiva al nacimiento de Jesús en sí o bien a lo que supuso para la humanidad. Se trata, pues, de una composición a lo divino calificada expresamente por su anónimo autor como "jacarilla al Nacimiento" (v. 17) y, en el verso anterior, como "ensalada burlesca" (v. 16). Ambas denominaciones nos llevan a reflexionar sobre lo que hay de ensalada en esta jácara y lo que tiene de jácara esta ensalada.

En la poesía española del siglo XVII, una ensalada llegó a ser una composición que brindaba la posibilidad de aunar otros poemas polimétricos, sin que se perdiera la motivación principal que dio origen a este tipo de estructura poética y que era la de

\footnotetext{
${ }^{3}$ Catálogo de Manuscritos de la Biblioteca Nacional con poesía en castellano de los siglos XVI y XVII. Edición dirigida por Pablo JAURALDE PoU. Madrid: Editorial Arco/Libros, 1998, 6 vols.

${ }^{4}$ LAMBEA, Mariano. Íncipit de poesía española musicada, ca. 1465 - ca. 1710. Madrid: Sociedad Española de Musicología, 2000. En breve ofreceremos actualizado este Íncipit bajo el título Nuevo íncipit de poesía española musicada, que podrá consultarse en acceso abierto en la Biblioteca Virtual Miguel de Cervantes <http://www.cervantesvirtual.com/>, en Digital CSIC <http://digital.csic.es/> y en Orfeo Hispánico <http://orfeohispanico.com/web/>.

${ }^{5}$ Xácara con variedad de tonos. Biblioteca de Catalunya, M. 753/24. Pedrell la describía en estos términos: "Xácara con variedad de tonos, al N.to (Acompanya la lletra de la xàcara ab 21 variants, algunes de genre popular)". PEDrell, Felip. Catàlech de la Biblioteca Musical de la Diputació de Barcelona. Barcelona: Palau de la Diputació, 1909, vol. II, pp. 55-56, nº 804.
} 
intercalar canciones partiendo de una base en octosílabo de carácter narrativo ${ }^{6}$. En esta ensalada que editamos hoy aquí, encontramos esta base en octosílabos tanto al inicio como al final. Los veintidós primeros versos son un diálogo entre tres personajes distintos y, al mismo tiempo, entre ellos y el público a quienes se dirigen presentándose. Es el caso del sastre y el poeta, responsables de la jácara, y que abren la composición en su calidad de autores irreverentes con las musas y el arte poético, lo que les da licencia para recurrir a un juego lingüístico trufado de frases hechas y continuos desafíos jocosos que son un preludio del estilo del resto de la obra, donde toda significación es una suma forzada de versos para mover a risa al oyente. El tercer personaje es Andresillo a quien corresponden los dos versos (vv. 21-22) que cierran la introducción y dan pie al inicio de la parte poético-musical. De ahí que su intervención sea un ruego para que la jácara empiece sin mayor demora. La segunda parte de esta base narrativa en octosílabos de la ensalada está formada por los versos en boca de un narrador que, a buen seguro, se trata del poeta o el sastre de la primera parte. Estos dos versos indican el término de la parte poético-musical dedicada al Nacimiento, y da entrada a una seguidilla compuesta que sella la composición.

Sin embargo, pese a que la estructura textual de la composición nos permitiría calificarla como ensalada, su carácter dialogístico interno y externo respecto al oyenteespectador la convierte en jácara; subgénero poético-musical que en el siglo XVII disfrutó de una gran popularidad gracias al teatro, ya que, en los entreactos, se representaba toda suerte de géneros teatrales menores, entre ellos la jácara que, aunque nazca del tono barroco, al entrar a participar en el espectáculo teatral de los corrales de comedia, se dramatizó en su estilo poético al recurrir, por ejemplo, al diálogo, y, también, en su ejecución, pues, además, era cantada por los músicos de la compañía ${ }^{7}$. De esta manera, por jácara podemos entender toda composición, con mayor o menor carácter dramático, integrada por una serie de canciones casi siempre satírico-burlescas. En la definición de la jácara del Diccionario de Autoridades ${ }^{8}$ encontramos un matiz importante que determina el carácter burlesco de este tipo obras, ya que debía contar "algún suceso particular o extraño" (Aut.), y ello, en un período como el Barroco, en el que la palabra poética extremó su expresión, permitía extraordinarios textos como el que nos ocupa. El magnífico asentamiento del romancero lírico a partir de $1580^{9}$, aportó, asimismo, la vocación por contar cantando de manera cada vez más sofisticada,

${ }^{6}$ Véase Tomán Navarro Tomás, Métrica española, Madrid, Labor, 1991, pp. 244, 295 y 297.

7 Véase Esther Borrego GutiérRez. Un poeta cómico en la corte. Vida y obra de Vicente Suárez de Deza. Kassel: Edition Reichenberger, 2002, p. 94, n. 65. Citamos por su interés: “Además de su condición de 'subgénero' dramático, en un principio por jácara se entendía el 'conjunto de jaques o rufianes' (COR), o la 'reunión de mozuelos de vida nocturna y alegre' (Aut). También presentaba una acepción musical y coreográfica: 'tañido que se toca para cantar y bailar' (Aut) o 'especie de danza formada al tañido o son propio de la jácara' (Aut). Esto explica también que el nombre de jácara se aplicara al subgénero que nació del 'tono'; era éste un romance que se cantaba a dos y tres voces por los músicos de la compañía, acompañados de guitarra, vihuela y arpa, que solía ser pastoril, caballeresco, jocoso...; algunas veces este romance era relativo a la vida de las gentes del hampa y se le llamó 'jácara'. He aquí el origen teatral de la forma”. Cfr. con CotARElo y Mori, Emilio. Colección de entremeses, loas, bailes, jácaras y mojigangas desde fines del siglo XVI a mediados del XVIII. Estudio preliminar e índices por José Luis SuÁrEZ y Abraham MADROÑAL. Granada: Editorial Universidad de Granada, 2000, vol I, p. cclxxix. Añade Cotarelo: "La maligna intención y travesura que las actrices sabrían dar a su canto cayó tan en gracia al público que ya no quiso otra clase de tono más que éste. Entonces se pensó en darle más variedad y amplitud, y de ahí la gran diferencia de jácaras: dialogadas, entremesadas, bailadas, sueltas e intercaladas en los entremeses y bailes que se hicieron y cantaron en todo el siglo XVII."

${ }^{8}$ Diccionario de Autoridades. Edición facsímil. Madrid: Editorial Gredos, 1990.

${ }^{9}$ Véase el estudio introductorio de Mariano LAMBEA y Lola JoSA a la edición crítica de $L a$ música y la poesía en cancioneros polifónicos del siglo XVII. (I). Libro de Tonos Humanos (1655-1656), Barcelona: CSIC, vol. I, 2000, pp. 19-29. 
y, a su vez, el éxito de la Comedia Nueva permitió que una suerte de ensalada conquistara un escenario y adquiriera la importancia de un entremés. El resultado gustó tanto que por jácara llegó a entenderse un modo de tocar instrumentos, de bailar y hasta de ser, pues jácara era, también, todo grupo de jóvenes que de noche hacían ruido y cantaban (jácaras) por las calles (Aut.).

En cuanto a la divinización de esta jácara, es muy importante que no afecte a los íncipits de los tonos, los cuales se mantienen invariables desde las fuentes profanas, sin que se les practique ningún tipo de contrafactum. Podríamos decir que se trata de una divinización por contexto, tal y como señala Carmelo Caballero: "lo más frecuente es que a lo largo de una de las secciones del villancico se citen varios fragmentos de diferentes tonos. En todos estos casos podemos hablar de 'divinización por contexto', dado que el material no sufre alteración apreciable alguna" ${ }^{\prime \prime}$. Ahí radica, precisamente, parte del valor de esta obra, pues con sumo ingenio se casa lo profano con lo sacro, en un trenzado de versos que, como el lector podrá comprobar en su lectura, no altera en ningún momento la reverencia y el respeto que merece, en última instancia, la trascendencia de la redención del hombre a través de Cristo. Por otra parte, no poca gracia causaría entre el público la mezcla de canto y declamación, puesto que la diversión surgiría al asociar una tonada conocida, perteneciente a un contexto también conocido, con la ocurrencia de los versos declamados ${ }^{11}$.

Los íncipits musicados vienen debidamente numerados en el original. Los ofrecemos aquí para que el lector los tenga a mano por si desea realizar búsquedas o confrontaciones:

1. Agora que la noche,/ con el horror y el sueño

2. Bellísimo Narciso,/ que a estos amenos valles

3. Breve animado mundo,/ desde el día infeliz

4. La beldad que en la pura/ idea soberana

5. Ya que aqueste peñasco/ cuya esmeralda bruta

6. Gigante cristalino/ que al cielo te oponías

7. Zagala de Manzanares/ que vienes a vender flores

8. Inocente mariposa/ que te arrojas a las llamas

9. Del desmayo, del susto, del miedo/ a cuyo pavor el sentido perdí

10. De la villa vino Antón/ enamoradito ayer

11. Infelices amantes,/ que afectando el sosiego

12. Abeja que al campo sales/ entre rosas y azucenas

13. Recibe, adorada ausente,/ estos suspiros cobardes

14. Moradores de Roma,/ iparad, prestad atención!

15. ¿No ves amar aquel risco/ aquella fuente, sin que...?

16. El curso transparente/ de su corriente clara

17. Don Pedro a quien los crueles/ llaman, sin razón, cruel

18. ¡Bárbaros moradores de Anoia,/ suspended, parad, despedid!

${ }^{10}$ CABAllero FernándeZ-Rufete, Carmelo. «Miscent sacra profanis: música profana y teatral en los villancicos de la segunda mitad del siglo XVII». En: Música y literatura en la Península ibérica 1600-1750. Actas del Congreso Internacional. Valladolid, 20-22 de febrero de 1995. María Antonia Virgili Blanquet, Germán Vega García-Luengos y Carmelo Caballero Fernández-Rufete (eds.). Valladolid: V Centenario Tratado de Tordesillas, 1997, p. 56.

${ }^{11}$ Dice Caballero "Algo más frecuente resulta la localización de citas de canciones profanas, preexistentes y presumiblemente conocidas por el auditorio. En estos casos el compositor sigue, desde luego, los dictados del poeta. Un marco relativamente habitual para la presentación de citas de música vocal profana son los villancicos «de personajes» (generalmente 'negros') quienes, dirigiéndose al portal de Belén y con el propósito de divertir al Niño, entonan diversas canciones" (Ibidem, pp. 55-56). 
19. Aglauros, infelice,/ que del sueño te vences

20. A las doce va por agua/ la zangarilleja

21. A la de Guadalupe,/ reina del cielo

\title{
El texto
}

\author{
JÁCARA ${ }^{*}$ \\ -Yo, un sastre, ;salvo, lugar! \\ -Yo, un poeta con licencia, \\ que es menester esta salva \\ para un sastre y un poeta. \\ -Zurcidor de tres, la una, \\ con una pluma tijera, \\ sé hacer vestidos a metros \\ como coplas a bayeta. \\ -Hoy día, que cumple años \\ doña Pascua, aquella vieja, \\ celebrada hija de doña \\ Navidad de Nochebuena, \\ mesclando todos los tonos, \\ como si mesclara yerbas, \\ pretendo hacer de las musas \\ una ensalada burlesca. \\ -Jacarilla al Nacimiento \\ va campando con su estrella.
}

\footnotetext{
${ }^{*}$ Los números de las siguientes notas críticas remiten al número del verso.

1. isalvo, lugar!: "hacer la salva" significaba pedir "permiso y licencia para hablar" (Aut.), y pedirlo al lugar quiere decir a quien escucha en ese momento y en ese lugar; es decir, al auditorio.

2. poeta con licencia: remite a la "licencia poética", a la libertad de la que se valía un poeta para permitirse contravenir las reglas (Aut.). La ironía estriba en que un poeta y un sastre juntos van a contravenir las reglas aun sin proponérselo, como confirman los versos siguientes.

3. salva: se juega con la doble acepción de pedir "licencia" para hablar (quedando, así, relacionado con el verso anterior y la licencia poética) y con el significado de "salva" en cuanto al "canto y música que las aves hacen cuando empieza a amanecer" (Aut.). Así pues, la jácara sería la salva al nacimiento-amanecer del Hijo de Dios.

5. Téngase en cuenta que por zurcir se entendía, asimismo, juntar "cualquier cosa con otra" (Aut.), que es lo que, supuestamente, van a hacer él y el poeta en la jácara.

8. En esta estrofa el sastre se burla de su capacidad poética, por eso dice que sabe hacer versos "a metros" y coplas "flojas y ralas", como lo es la tela de la bayeta.

14. Entiéndase, de cualquier manera, sin exigencia poética.

16. La ensalada llegó al siglo XVII ofreciendo la posibilidad de coordinar composiciones polimétricas, pero sin perder la motivación principal que le dio origen y que fue intercalar canciones sobre una base poética en octosílabo de carácter narrativo. Tal y como podemos comprobar en esta jácara que es, por lo tanto, una ensalada.

18. Campar con su estrella significa "hacer que resplandezca la fortuna propia en acciones y palabras, y también envanecerse de que le sigue en todo una buena suerte" (Aut.). Además, debemos sumarle la referencia a la estrella de Belén que guiaba al portal del Nacimiento.
} 
¡Atención, porque, en lugar de un “¡Agua va!” allá va ella!

-¡Jácara -dijo Andresillo-, aunque sea a troche y moche!:

Agora que la noche, con el horror y el sueño, quitando a la muerte el ceño, inviar a los hombres quiso

\author{
bellísimo Narciso, \\ que a estos amenos valles \\ has nacido porque halles \\ en su silencio profundo
}

breve animado mundo, desde el día infeliz.

para la mortal cerviz que labra nuestra ventura;

la beldad que en la pura idea soberana se escogió para que ufana le diese al demonio un chasco.

Ya que aqueste peñasco cuya esmeralda bruta en cada arroyo tributa (sin ser arroyo divino)

20. ¡Agua va! era la expresión con la que se avisaba "a los que pasaban por la calle que se arrojaba por las ventanas o canalones alguna agua o inmundicia" (Aut.). Por lo tanto es como si el sastre y el poeta "arrojaran" la jácara de improviso al oyente.

22. Estos dos versos son la transición entre el preámbulo de la jácara y su inicio poético musical propiamente. Igual función tienen los versos 103-104 al cierre de la jácara; a troche y moche se encuentra recogido en Aut. como frase adverbial: "atrochemoche", que significa "disparatada e inconsideradamente, sin reparo ni consideración alguna"; sentido que guarda relación como respuesta a lo que comentábamos en la nota anterior.

25. ceño: "metafóricamente se llama así lo desapacible, desagradable, enfadoso u triste de cualquier cosa" (Aut.); en este caso, la muerte, porque el nacimiento de Jesús supuso la promesa de la vida eterna para el hombre.

26. inviar: enviar.

27. Se refiere a Jesús.

31. breve: "transitorio" (Aut.). y el trabajo.

34. Desde el día de la caída de Adán y Eva que sumió al hombre en el sufrimiento, la ignorancia

38. Jesús permite el retorno del hombre al paraíso, y, en consecuencia, frustrar la intención satánica de que viva siempre en el pecado y alejado de Dios.

39. Dentro de la ficción de la jácara, el lugar del nacimiento, como nos ayuda a entender el verso 79.

40. esmeralda bruta: metáfora del pequeño Jesús, considerado piedra preciosa en estado bruto, porque es un recién nacido. 
gigante cristalino
que al cielo te oponías.

Dijo un ángel sin porfías

a una santa de Pajares:

«Zagala de Manzanares

que vienes a vender flores,

ve y dile a los pastores

que en ese portal reposa».

Inocente mariposa

que te arrojas a las llamas,

viendo el demonio estas tramas

les dio asomos a pie quedo.

Del desmayo, del susto, del miedo

55

a cuyo pavor el sentido perdí.

Mas no le valdrá, p[ues] vi

que, al ver esta admiración,

de la villa vino Antón

enamoradito ayer;

vino Gil y su mujer

los que fueron ahora y antes

infelices amantes,

que afectando el sosiego

trujisteis en un talego

miel que tributa en panales.

\footnotetext{
Abeja que al campo sales

entre rosas y azucenas,

libando en dulces colmenas

dices con gemido ardiente:
}

70

«Recibe, adorada ausente, estos suspiros cobardes,

que antes de cincuenta tardes

dirán tres reyes de edad:

44. La "esmeralda bruta" nacida en el peñasco pasa a dignificarlo todo, y contribuye (tributa, v. 41) a engrandecerlo todo, a hacer posible que un simple arroyo, pese a su insignificancia (a esto alude el v. 42) acabe siendo agua del propio mar (gigante cristalino) que en la imaginería cristiana es metáfora de Dios. En definitiva, Jesús redime de las limitaciones y permite la reconciliación con Dios.

45. sin porfías: sin disputas ni contiendas (Aut.).

46. Pajares: pueblo de la provincia de Asturias.

50. Se entiende que el niño Jesús.

53. tramas: "artificio engañoso y astuto con que se perjudica a alguno" (Aut.); en este caso las tramas de las llamas porque con su luz atraen a la mariposa.

54. asomos: "indicios o señales" (Aut.); a pie quedo: "sin trabajo", sin esfuerzo propio (Aut.). Es decir, el demonio facilitó las tramas del fuego, puesto que es el elemento que caracteriza el infierno. 
-Moradores de Roma,

¿No ves amar aquel risco

aquella fuente, sin que

de su rendimiento en fe embarga el ver tanta gente?

\section{El curso transparente}

de su corriente clara,

cuando al infante prepara

cogerle con sus infieles,

don Pedro a quien los crueles

llaman, sin razón, cruel,

y en eso mienten, que él excede en su Babilonia.

¡Bárbaros moradores de Aonia, suspended, parad, despedid!

Mas no le valdrá el ardid, aunque lo contrario dice.

Aglauros, infelice, que del sueño te vences, y aunque sepas más vascuences que la tonada que fragua,

a las doce va por agua

la zangarilleja

a los caños del peral.

¡Zarandillo andar!

74. Los reyes de diferentes orígenes que acudieron al nacimiento de Jesús para adorarlo (Mt, 2 , 12).

78. máscara: entendamos, rostro; cisco: "carbón" (Aut.). Por lo tanto, el rostro de color negro, tal y como la iconografía tradicional representa a uno de los reyes que acudieron al nacimiento de Jesús, como representante de una de las razas (la etíope) de la humanidad.

79-80. risco - fuente: metáforas de Jesús, por su solidez y altura, y porque sacia la sed de todo aquel que se acerque a él.

88. Se refiere a Pedro I de Castilla (1350-1369), apodado el Cruel por sus enemigos.

90. Alusión satírica a la compleja vida política y amorosa de este monarca castellano, entre esposas, amantes y traiciones de todo tipo.

91. Aonia o Beocia es la región donde se encontraban el monte Helicón y la fuente Hipocrena, consagrados a las musas.

95. Aglauros, según la mitología, princesa ateniense convertida en piedra (del sueño te vences) por el dios Hermes para castigar la traición que le hizo al dios cuando buscaba a su amada Herse.

100. zangarilleja: "la muchacha o moza puerca y mal vestida que anda vagando" (Aut.).

102. Zarandillo: "el que con viveza y ligereza anda de una parte a otra" (Aut.). Apréciese que este término permite jugar con la palabra "zangarilleja". 


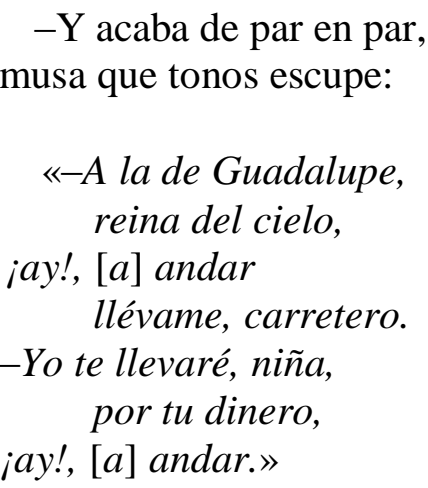

\section{La música}

Los investigadores que estudiamos los tonos humanos y la música en el teatro áureo sabemos que, prácticamente, no se han conservado las partituras de lo que se cantaba en las comedias y en los géneros breves como el entremés, el baile, la jácara, la mojiganga, etc. Es por ello que esta jácara tiene mayor relevancia pues, además de estar compuesta con intención dramática, nos transmite melodías que, casi con total certeza, se cantarían en escena; algunas de ellas completamente desconocidas como hemos señalado anteriormente.

Por otra parte, nos planteamos, también, la coherencia musical de esta obra, es decir, si su anónimo compositor -o centonizador- tuvo intención de dar unidad al conjunto y si mostró también la suficiente habilidad para que la jácara, en su vertiginosa sucesión de citas de tonos, tuviera la necesaria lógica musical. Juzgue el lector por sí mismo. Por nuestra parte creemos que sí la tuvo; incluso el compositor llegó a variar algunos finales de los fragmentos de los tonos citados para alcanzar un mayor dinamismo musical y facilitar la expresividad y la fluidez del discurso. En relación a la actividad de los músicos en el teatro dice Flórez lo siguiente:

[Los músicos,] obligados a poner la música del día a día, y normalmente con tal premura de tiempo que no permitiría obras excesivamente pulidas, no podemos descartar que recurriesen a una serie de fórmulas más o menos estereotipadas que si bien podían perjudicar la calidad de la obra, en cambio les permitían cumplir con su obligación de poner música al amplio repertorio que debía presentar cada temporada una compañía. ${ }^{12}$

En cuanto a la transcripción de esta pieza seguimos los criterios que hemos adoptado siempre en nuestras ediciones del Libro de Tonos Humanos y del Cancionero Poético-Musical Hispánico de Lisboa que el lector, sin duda, ya conoce y que no vamos a repetir aquí. La única dificultad que hallamos para transcribir esta obra es la presencia de unos asteriscos en determinados tonos; a saber: 1, 2, 4, 7, 10, 13 y 15. Quizá estos asteriscos indiquen una interpretación a cargo de un tenor a pesar de estar escritos en clave de Do en primera línea, ya que si los transcribimos para voz de tiple, como indica

105. Guadalupe: el copista, que es catalán, encima de "Guadalupe" escribió "Montserrate", el nombre de la virgen negra que iba a convertirse en la patrona de Catalunya. Quizá como advertencia de la posibilidad de cantar esta letra, en concreto, en honor a la Moreneta.

109. niña: "ninya" en el original; se trata de otra huella de la lengua materna del copista.

${ }^{12}$ FlóREZ AsEnsio, María Asunción. «'Salgan racionales ruiseñores’. Músicos de las compañías teatrales de Madrid durante el siglo XVII». En: Revista de Musicología, XXXI, 1 (2008), p. 54. 
esa clave, no es posible que concuerden con el acompañamiento. Avalan nuestra suposición las fuentes paralelas de los tonos 2 y 13. También se dan algunas incongruencias en los fragmentos escritos en la clave de SoL en segunda línea, donde lo más lógico es transcribirlos a la cuarta justa inferior. Así se debe hacer en los tonos 3 , 17 y 21 , pero no parece que sea necesario en el 14 ni en el 16. En relación al tono 21, que cierra la jácara, creemos que podría ser interpretado por un tiple hasta el compás 9 y por un tenor desde el compás 10 hasta el final. El sentido del texto así lo indica y las notas de los compases 16 y 18 son muy graves para un tiple, pero no para un tenor. Sea como fuere, las circunstancias de la interpretación de esta obra en escena permanecen vedadas para la investigación. Es cierto que por el sentido del texto podemos inferir que tal o cual tono se cantaría por un tiple o por un tenor, pero tampoco son certezas que nos convenzan totalmente. Una cosa son los tonos originales que se interpretarían en la corte o en el teatro musical con indicación específica de la voz, y otra muy distinta es este baturrillo de fragmentos de ellos que se canta en la jácara.

\section{Fuentes poético-musicales}

1. Agora que la noche,/ con el horror y el sueño

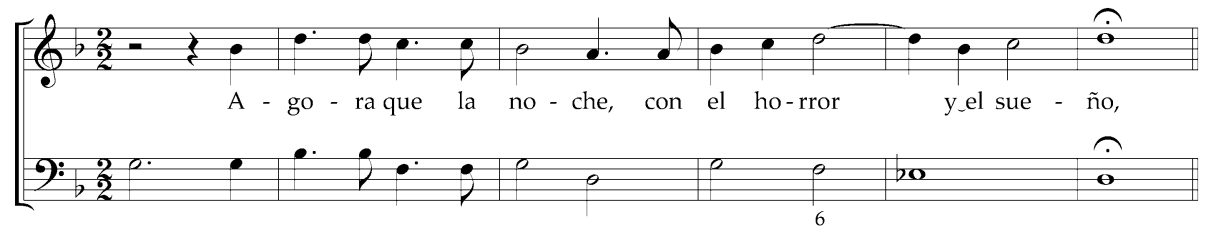

IPEM, p. 60.

Stein, p. 363.

Flórez, p. 111.

Retomamos aquí parte de los comentarios que hicimos sobre este tono en la reseña que escribimos sobre el libro de Flórez ${ }^{13}$. Señala la autora algunos aspectos de $E l$ persiano fingido (1674), entremés cantado de Gil López de Armesto, que incluye en su trama la primera cuarteta de una de las barquillas que Lope de Vega insertó en La Dorotea (1632); aquella que dice: «Para que no te vayas,/ pobre barquilla a pique,/ lastremos de desdichas/ tu fundamento triste». Flórez nos refiere que dicha cuarteta la cantan, en el entremés citado, "Sebastiana y Luisa Fernández", célebres actricescantantes de la época, de la misma manera que "Luisa Romero y Mariana" cantan unos versos que empiezan así: "Ahora que la noche/ con el horror y el sueño». En la línea de Stein, Flórez aporta más datos y nos informa detenidamente de aspectos interesantísimos. Por nuestra parte, no queremos dejar pasar la oportunidad de comentar lo siguiente: la cuarteta de Lope, y varias más que obviamos en aras de la brevedad, se hallan puestas en música por el compositor Bernardo Murillo en el Libro de Tonos Humanos $^{14}$, a cuatro voces (SSAT), en un estilo imitativo que alterna las parejas de las voces en terceras paralelas (bicinia) y que, a tenor de lo que nos dice Flórez, no sería de

${ }^{13}$ LAMBEA, Mariano y JOSA, Lola. [Reseña bibliográfica sobre el libro de María Asunción Flórez, Música teatral en el Madrid de los Austrias..., citado anteriormente]. En: Revista de Musicología, XXX, 1 (2007), pp. 288-298, <http://hdl.handle.net/10261/10018>.

14 Véase LAmBEA, Mariano y JosA, Lola (eds.). La música y la poesía en cancioneros polifónicos del siglo XVII. (II). Libro de Tonos Humanos, vol. II. Madrid-Barcelona: CSIC, 2003, pp. 34 y 52-53 (texto), y 133-136 (música). 
difícil interpretación para las actrices-cantantes que ella refiere. Para los otros dos versos no conocemos testimonio musical polifónico ni tampoco a dúo, a pesar de que sería un tono famoso en aquel tiempo; sólo se nos ha conservado el inicio para voz sola de nuestra jácara. Es posible que en el entremés que menciona Flórez se cantara una versión a dos o más voces, que presentaría una cita intertextual de la frase musical de la jácara, pero esto no lo sabemos. Lo que sí sabemos es que la estrofa que incluyó López de Armesto -que dice así: "Ahora que la noche,/ con el horror y el sueño/ los ojos a el ocioso/ y a el desvelado roba los afectos"- es la primera de unas endechas reales escritas por Antonio de Solís y Ribadeneyra que, tras la lectura que hemos hecho de ellas, nos permiten llegar a la conclusión de que el yo poético opta por morir de amor ante la imposibilidad de tener a Filis. En definitiva, y ya para no extendernos más, recapitulamos: en un entremés "representado y cantado" de López de Armesto hallamos versos de un romancillo piscatorio que Lope escribe e inserta en una acción dramática en prosa con tintes de novela autobiográfica como es La Dorotea; versos de Antonio de Solís, secretario privado de Felipe IV y comediógrafo de éxito en su tiempo, que él mismo define como "sentimientos de un amante que se hallaba empeñado en perder a su dama"; la interpretación de dos cantantes-actrices que, muy probablemente, cantarían la música que Bernardo Murillo destinó a la barquilla lopesca y que se nos ha conservado en un códice, el famoso Libro de Tonos Humanos, copiado por el capón Diego Pizarro para el Convento del Carmen de Madrid; y, por último, otra interpretación musical que, quizá, estuviera basada en la melodía que nos ha transmitido la jácara que nos ocupa. Es evidente que los poemas y las músicas de nuestro Siglo de Oro conforman una auténtica maraña de referencias, citas intertextuales, préstamos, remisiones, etc., con un sinfín, además, de autores conocidos y anónimos Y todo ello bien mezclado y dispuesto, para que nosotros, musicólogos y filólogos, intentemos poner orden en todo este entramado poético-musical.

2. Bellísimo Narciso,/ que a estos amenos valles

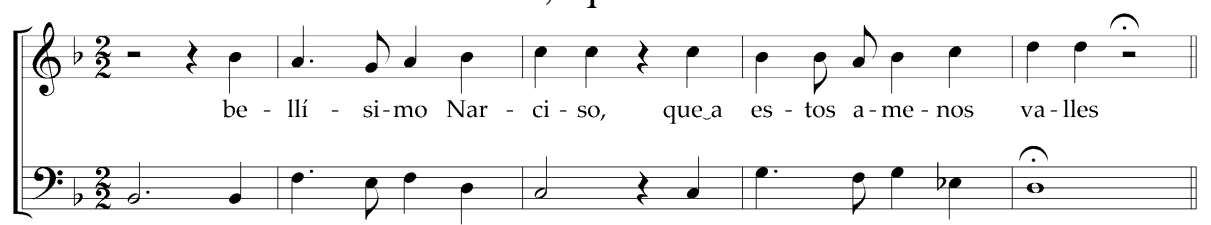

Manuscrito Novena, p. 237. [¿Juan Hidalgo?] Museo Nacional del Teatro (Almagro)

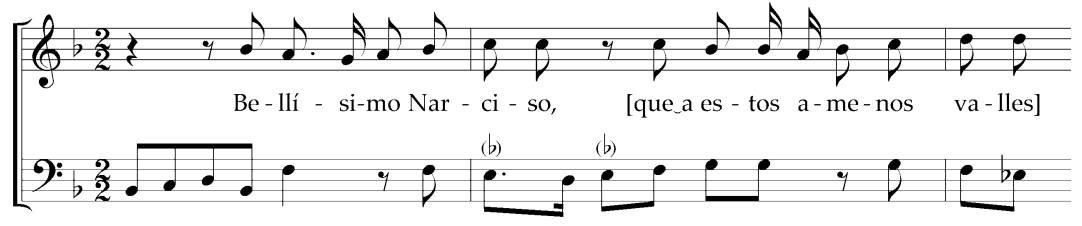

IPEM, pp. 90-91.

Stein, p. 369.

Flórez, p. $301^{15}$.

${ }^{15}$ "Se trata de una tonada muy popular en el siglo XVII, tanto en España como en el Nuevo Mundo, ya que Juana Inés de la Cruz la utiliza en dos contextos completamente diferentes: como letra que acompaña al sainete que se representó con su comedia Los empeños de una casa, y como canción, con 
Sobre este tono es interesante consultar el artículo de José Máximo Leza ${ }^{16}$.

No hay variantes literarias.

Las diferencias musicales entre ambas versiones son los valores más breves en el Manuscrito Novena y algunas notas en el acompañamiento que pueden implicar armonizaciones diferentes; sugerimos aquí Mi b para el segundo compás.

3. Breve animado mundo,/ desde el día infeliz

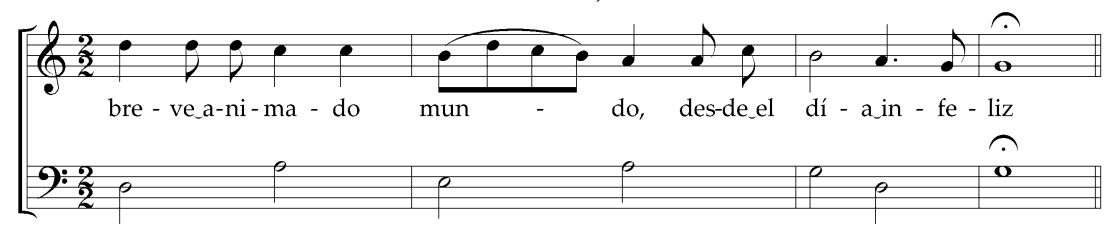

Música en la Comedia de Falerina. Anónimo

Biblioteca de Catalunya, M. 747/4

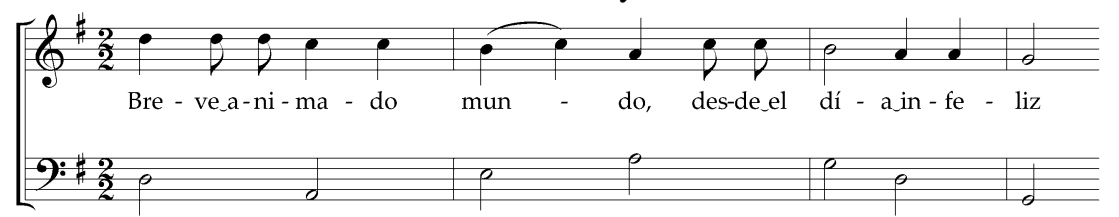

IPEM, p. 92.

Stein, p. 370; p. 436 (música).

No hay diferencias literarias.

Escasísimas diferencias melódicas entre ambas versiones.

4. La beldad que en la pura/ idea soberana

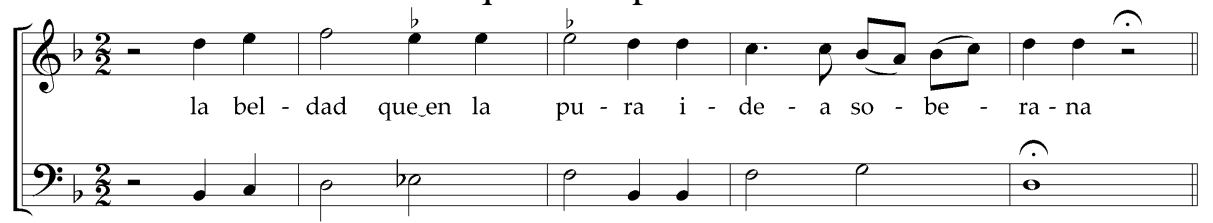

IPEM, p. 180.

Stein, p. 384 "Tono que se cantó en el coliseo del Retiro".

Rita Goldberg cita este tono como perteneciente al Libro de tonos puestos en cifra de $\operatorname{arpa}^{17}$ (Ms. 2478 de la Biblioteca Nacional), pero, como se sabe, sólo la cuarta

fuertes connotaciones seductoras, dentro de su auto sacramental El divino Narciso. También Miguel Gómez Camargo la utilizó trovada a lo divino al menos en dos ocasiones [y cita a Carmelo Caballero]" (FLóREZ. Música teatral en el Madrid..., p. 301).

${ }^{16}$ LEZA, José Máximo. «'Bellísimo Narciso’ y músicas para seguir siéndolo. Transformaciones dramatúrgicas en el teatro español entre los siglos XVII y XVIII». En: Concierto barroco. Estudios sobre música, dramaturgia e historia cultural. Juan José CARRERAS y Miguel Ángel MARÍN (eds.). Logroño: Universidad de La Rioja, 2004, pp. 47-76.

${ }^{17}$ Véase GoldBerg, Rita (ed.). Tonos a lo divino y a lo humano recogidos por el licenciado D. Gerónimo Nieto Madaleno [...] y escriptos por [...] Manuel López Palazios. London: Tamesis Books Limited, 1981, p. 29. 
parte de las obras de este manuscrito están en cifra de arpa; el resto son poesías sin música, entre las que se encuentra, precisamente, la que corresponde al tono de la jácara.

5. Ya que aqueste peñasco/ cuya esmeralda bruta

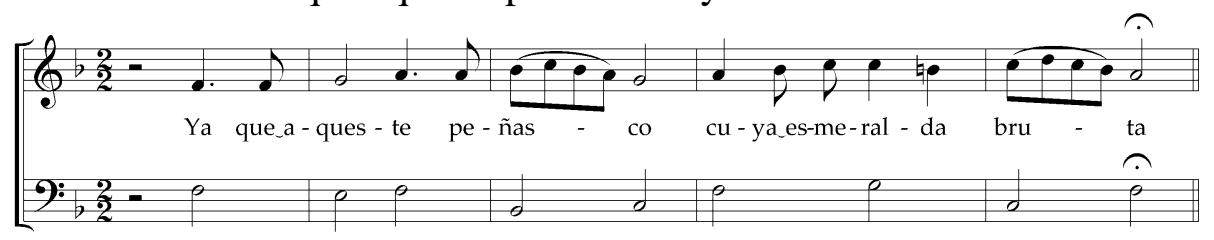

Celos aun del aire matan. Juan Hidalgo

De la transcripción de F. Bonastre

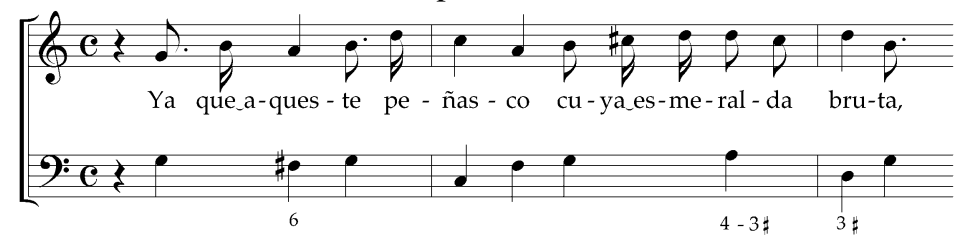

IPEM, p. 324.

Stein, p. 407; p. 495 (música).

Flórez, p. 349, n. 706.

Bonastre, p. $423^{18}$.

Sin diferencias literarias.

Las musicales son las siguientes: en la versión de Juan Hidalgo, es decir, en la original, destacan las notas escapadas del primer compás. En la jácara se adornan con melismas las cláusulas de los dos versos. En relación a la semitonía subintelecta conviene comparar el compás 2 de Hidalgo con el compás 4 de la jácara.

En la última nota del acompañamiento la jácara trae RE, pero encima de esta nota figura un FA tachado. Creemos que esta última nota es la que corresponde y así la transcribimos.

6. Gigante cristalino/ que al cielo te oponías

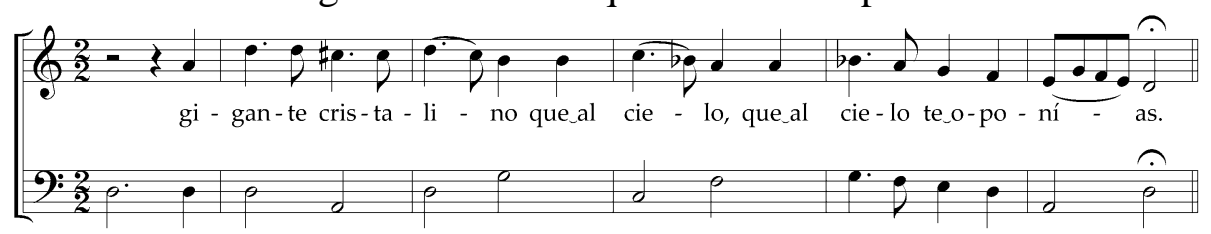

Libro de Tonos Humanos. [Manuel Correa]

${ }^{18}$ HidALGO, Juan. Celos aun del aire matan. Francesc BonASTRE (ed.). Madrid: ICCMU, 2000, p. 423. 


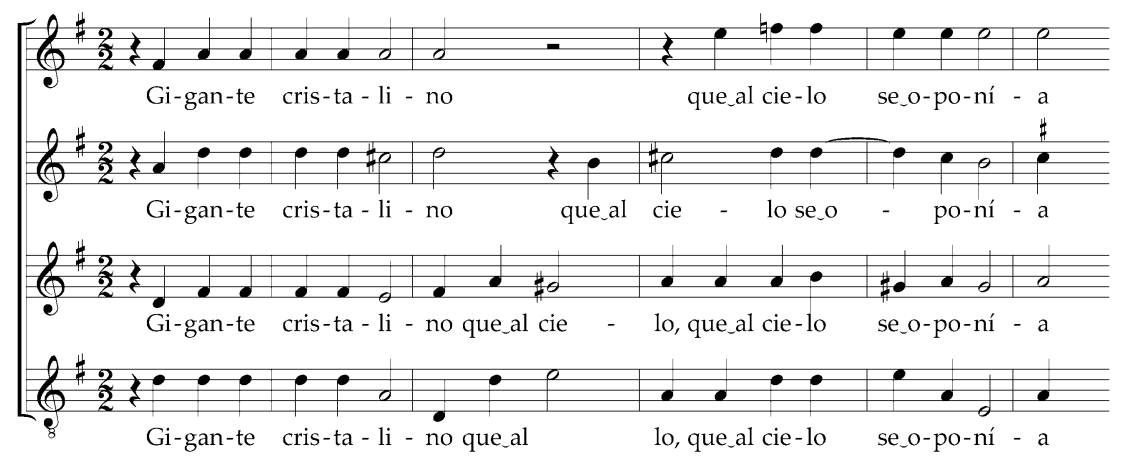

IPEM, p. 165.

Stein, p. 381.

Lambea y Josa. ${ }^{19}$

Sólo hay dos variantes en ambos textos poéticos.

En la música las diferencias son mucho más apreciables e interesantes. En primer lugar valoramos la cita intertextual de la jácara presente en el tiple segundo del Libro de Tonos Humanos cuya interválica inicial es similar, aunque rítmica y prosódicamente haya diferencias. La jácara prosigue después libremente, tanto en la melodía como en la armonía. Hablando en nuestra terminología diremos que en el testimonio polifónico se modula a LA, mientras que en la jácara se modula a FA. Conviene decir que podemos otorgar la autoría de esta obra a Manuel Correa por hallarse su nombre en la versión del Cancionero Musical de Onteniente, cuya música es la misma a pesar de haberse conservado solamente el tiple primero ${ }^{20}$.

Nos interesa la cronología del tono de Correa y su pervivencia a lo largo del siglo XVII. Es probable que su fecha de composición fuera anterior a 1630 porque el texto, que es un romancillo de Lope de Vega (1562-1635), pertenece a las famosas Barquillas del fénix que fueron incluidas en su obra en prosa La Dorotea antes de su publicación en 1632. Diego Pizarro, el copista del Libro de Tonos Humanos, trasladó el romancillo lopesco musicado por Correa entre 1655-1656. Por su parte, Agustín Moreto citó la primera cuarteta de «Gigante cristalino», intercalándola entre sus propios versos de su Entremés del vestuario ${ }^{21}$, estrenado en 1661, de la siguiente manera:

$\begin{array}{ll}\text { Música } & \text { "Gigante cristalino... } \\ \text { MANUELA } & \text { Acaba con el diablo. } \\ \text { Música } & \text {...al cielo se oponía... } \\ \text { MANUELA } & \text { Prende esas puntas bien. } \\ \text { Música } & \text {...el mar con blancas torres... } \\ \text { MANUELA } & \text { ¡Malhayas tú! } \\ \text { Música } & \text {...de espumas fugitivas”. } \\ \text { ESCAMILLA } & \text { ¡Jesús, la gente viene mal sentada! } \\ \text { GASPAR } & \text { De todo el tono no han oído nada. }\end{array}$

19 Véase LAmBeA, Mariano y JOSA, Lola (eds.). La música y la poesía en cancioneros polifónicos del siglo XVII. (IV). Libro de Tonos Humanos. Madrid: CSIC, 2005, vol. III, pp. 45 y 101-103 (texto), y 292-294 (música).

20 Véase El Cançoner Musical d'Ontinyent. Josep CLIMENT (ed.). Ontinyent: Ajuntament d'Ontinyent, 1996, pp. 198-199 (facsímil), pp. 379-382 (transcripción musical; Climent completa la pieza con la versión del Libro de Tonos Humanos) y pp. 507-508 (texto).

${ }^{21}$ Véase Lobato, María Luisa (ed.). Loas, entremeses y bailes de Agustín Moreto. Kassel: Edition Reichenberger, 2003, vol. II, p. 559. 
El entremés de Moreto es una pieza metateatral con esta única intervención musical que, entre el barullo de la acción y la escasa atención que le prestarían los espectadores, apenas se escuchó en escena; así nos lo dice el dramaturgo: "de todo el tono no han oído nada". No ocultaremos nuestra decepción...

Con todo lo referido podemos asegurar una pervivencia del tono «Gigante cristalino» de unos cincuenta años aproximadamente, puesto que nuestra jácara no puede ser anterior a 1675 (recordemos que contiene versos de Calderón, fallecido en 1681); además, nadie nos asegura que la jácara haya de ser el último testimonio de este célebre romancillo ${ }^{22}$.

7. Zagala de Manzanares/ que vienes a vender flores

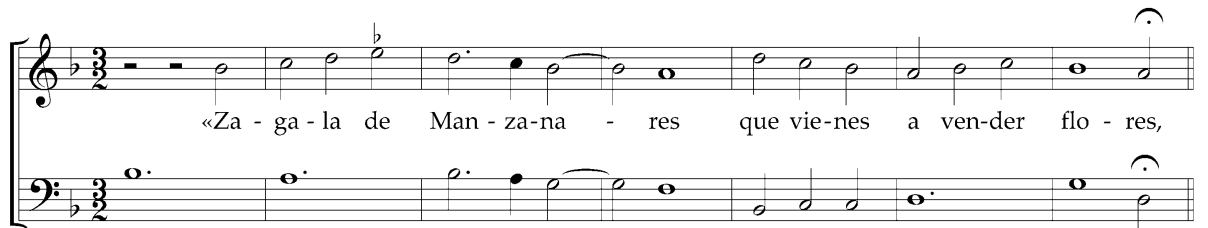

IPEM, p. 281 "Serrana de Manzanares".

Para las fuentes literarias es de capital importancia tener en cuenta la primera palabra de su íncipit, ya que es una variante: "Zagala" en unos testimonios y "Serrana" en otros. También algunas fuentes poético-musicales presentan ambigüedades en esas palabras, pero son obras diferentes a la que nos ocupa.

En el Ms. 4123 de la Biblioteca Nacional consta el Baile de la abejuela, de Alonso de Olmedo, en cuyo inicio un zagal canta la siguiente cuarteta, seguramente con la música de nuestro tono:

Serrana que a Manzanares

te vienes a vender flores

y con la flor de la aldea

te llevas la de la corte ${ }^{23}$.

El Ms. 888 de la Biblioteca de Catalunya es un Libro de diversas letras (1689), algunas de las cuales traen cifras para guitarra, entre ellas el tono de la jácara. Esta importante fuente ha sido descrita por M. June Yakeley ${ }^{24}$ y estudiada por Francisco Valdivia ${ }^{25}$, quien, en relación a nuestro tono, dice: "Sólo son los dos primeros versos,

${ }^{22}$ Hemos estudiado todos los avatares de «Gigante cristalino» en los siguientes trabajos: JOSA, Lola y LAMBEA, Mariano: «'Lisonjas ofrezca' Agustín Moreto: intertextualidades poético-musicales en algunas de sus obras». En: De Moretiana Fortuna. Estudios sobre el teatro de Agustín Moreto. María Luisa Lobato y Ann L. MACKenZIE (eds.). Bulletin of Spanish Studies, LXXXV, 7-8 (2008), pp. 153172; y JOSA, Lola y LAMBEA, Mariano: «Metamorfosis del tono humano barroco: variantes, pervivencias e implicaciones musicales en el teatro del siglo XVII». En: Homenaje a Luciano García Lorenzo. Madrid: CSIC, (en prensa).

${ }^{23}$ Véase MerIno QuiJano, Gaspar. Los bailes dramáticos del siglo XVII. Madrid: Universidad Complutense, 1980, vol. II, p. 227 [tesis doctoral fotocopiada].

${ }^{24}$ Véase YAKELEY, M. Yune. «New sources of spanish music for five course guitar». En: Revista de Musicología, XIX, 1-2 (1996), pp. 275-276.

${ }^{25}$ Véase VAldivia Sevilla, Francisco A. Música popular y comunicación en la España del, siglo XVII: los sistemas de notación abreviada de acordes de guitarra. Trabajo de investigación para el DEA. Universidad de Málaga. Facultad de Ciencias de la Comunicación, curso 2007-2008, p. 71. Agradecemos al autor las facilidades que tan amablemente nos ha otorgado para la consulta de su trabajo. 
con la melodía y el acompañamiento, que son idénticos - con la salvedad de «Zagala» por «Serrana»- a los dos primeros del Ms 888. No es posible establecer mayores paralelismos entre ambas versiones, al carecer una de más versos y estar la otra prácticamente desprovista de cifras.”

8. Inocente mariposa/ que te arrojas a las llamas

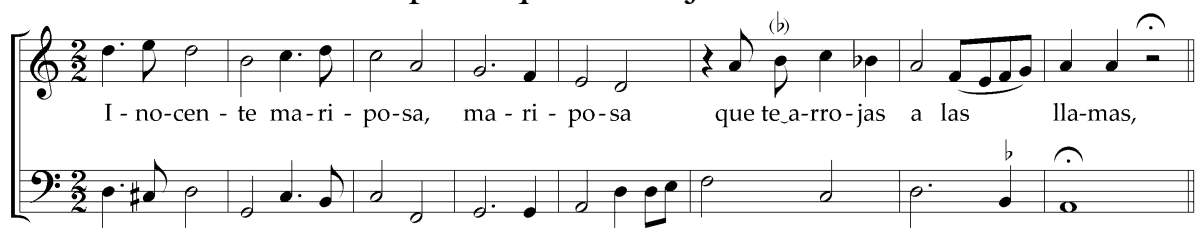

Cancionero Poético-Musical Hispánico de Lisboa, ff. 95v-96v. Anónimo

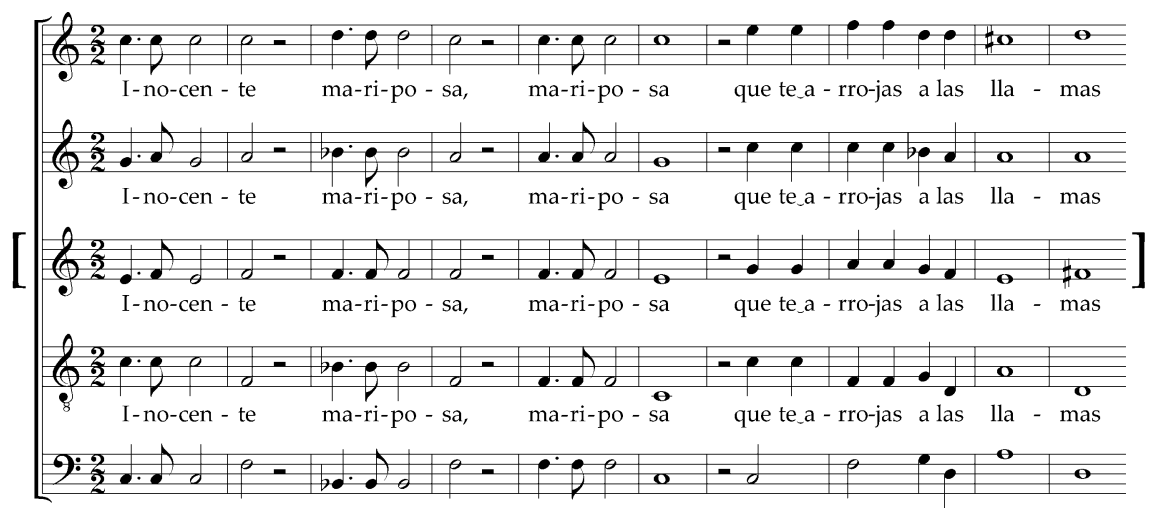

IPEM, p. 176.

Stein, p. 383. "mariposa".

El texto es igual en ambas versiones; incluso ambas repiten la palabra

La confrontación musical de las dos versiones nos ofrece datos interesantes. «Inocente mariposa» es un tono humano a cuatro voces perteneciente al Cancionero Poético-Musical Hispánico de Lisboa que estamos editando en la SEdeM y en el $\mathrm{CSIC}^{26}$. Como se sabe, a este cancionero le falta una voz, afortunadamente intermedia, lo que hace factible su reconstrucción. En fragmentos homofónicos, como el que nos ocupa, no hay problema en escribir la voz que falta, tal y como puede observarse en el ejemplo que transcribimos. Otra cuestión son los pasajes en contrapunto imitativo, que son mucho más complicados de encajar con plena satisfacción.

En «Inocente mariposa» sucede algo similar a lo que ocurría en «Gigante cristalino», es decir, la jácara remeda en su inicio los dos primeros compases del tono humano, tanto rítmica, como armónica y melódicamente. La melodía de la jácara es preciosa. Destacan las pausas en el tono humano y la ausencia de las mismas en la jácara; seguramente en este caso para obtener un mayor dinamismo en la representación.

26 Véase LAMBEA, Mariano y JosA, Lola (eds.). La música y la poesía en cancioneros polifónicos del siglo XVII. (III). Cancionero Poético-Musical Hispánico de Lisboa. Madrid: SEdeM, 2004, vol. I; y (V), Madrid: SEdeM / CSIC, 2006, vol. II. «Inocente mariposa» se publicará en el siguiente volumen. 
Todo el ambiente del tono humano (lo hemos advertido en la transcripción completa) se ve reflejado después en la jácara, que es posterior en varias décadas, puesto que el cancionero lisboeta fue compilado hacia 1635. Incluso la textura musical de este tono podría hacernos pensar que fue compuesto a principios del siglo XVII.

En estos tonos polifónicos siempre albergamos dudas para discernir qué línea melódica es la más relevante: muchas veces nos dejamos guiar por la que presenta una interválica más variada; otras veces, es evidente que no hay ninguna melodía aislada, y que es el conjunto polifónico el que prima. Podemos decir que en la jácara se han transmitido las melodías que corresponderían a las tonadas principales; y creemos que éste es un detalle importante.

9. Del desmayo, del susto, del miedo/ a cuyo pavor el sentido perdí

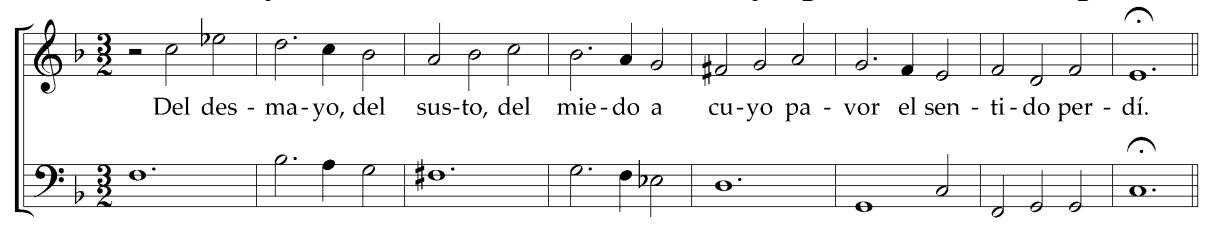

Celos aun del aire matan. Juan Hidalgo

De la transcripción de F. Bonastre

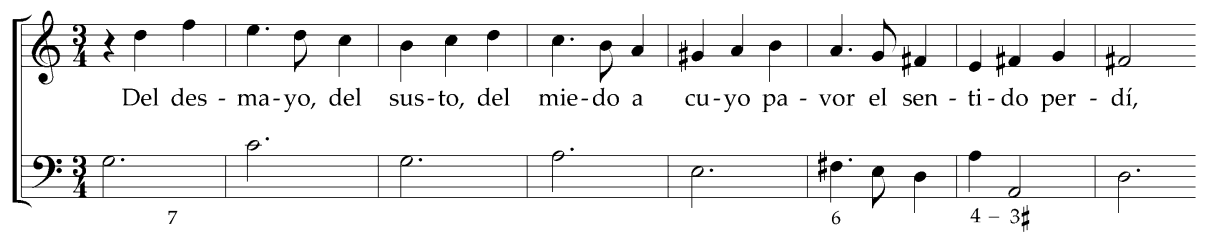

BN, Ms. 3881/47. Anónimo

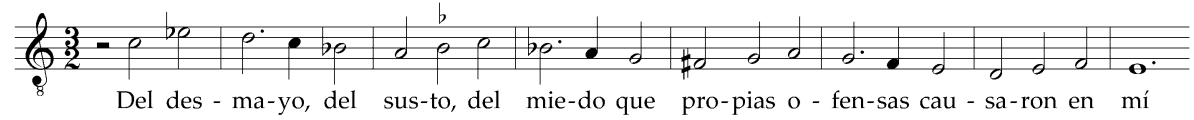

BC, M. 759/5. Anónimo

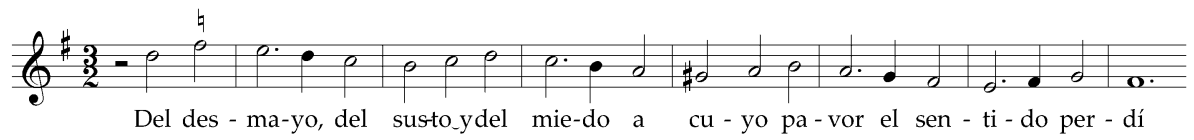

IPEM, p. 125.

Stein, p. 375.

Bonastre, p. $432^{27}$.

Las diferencias del texto más significativas son las que constan en el Ms. 3881/47 de la Biblioteca Nacional, concretamente en el segundo verso: "que propias ofensas causaron en mí". Es importante también constatar que en otro manuscrito de esta biblioteca, el Ms. 4123, se conserva el Baile de la Forastera de la corte, cuya estrofa inicial dice así:

\footnotetext{
${ }^{27}$ Hidalgo. Op. cit., p. 432.
} 
Forastera a la corte me vengo, por si acaso puedo fortuna adquirir con mi cara, pues sólo en la corte se estima el donaire y el garbo gentil.

Esta estrofa, según la acotación, se canta "por el tono del desmayo", o sea, por nuestro tono, ya que la métrica de los versos encaja perfectamente ${ }^{28}$.

De la música hay varias versiones, y todas son interesantes por uno u otro motivo; obsérvense las diferencias armónicas entre la versión de Celos aun del aire matan y la de la jácara.

La versión del Ms. 3881/47 de la Biblioteca Nacional viene precedida, al parecer, por un estribillo cuyos primeros versos dicen así: "Querer y olvidar/ puede ser querer,/ pero no es amar..."

Carmelo Caballero dice de este tono lo siguiente: "La copia que nos proporciona Miguel Gómez Camargo sólo incluye la parte vocal y el texto de la primera estrofa del solo cantado por Pocris. Dado que la versión es idéntica a la que se conserva en el manuscrito de Evora, ha sido posible completar el acompañamiento continuo a partir de este último. El tono -como otros que tienen una estructura estrófica- debió popularizarse rápidamente, dada su presencia independiente en varios manuscritos poéticos y musicales de finales del siglo XVII. Además de la fuente lusitana Louise K. Stein cita otras dos - una de ellas incompleta- conservadas en la Biblioteca de Cataluña, en Barcelona ${ }^{29 "}$.

10. De la villa vino Antón/ enamoradito ayer

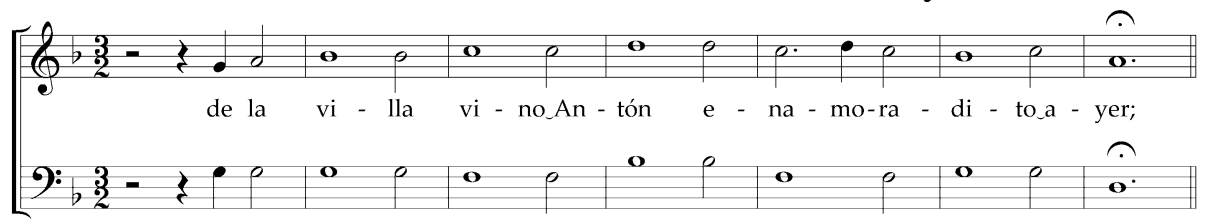

No hemos hallado ninguna fuente poético-musical de este tono.

11. Infelices amantes,/ que afectando el sosiego

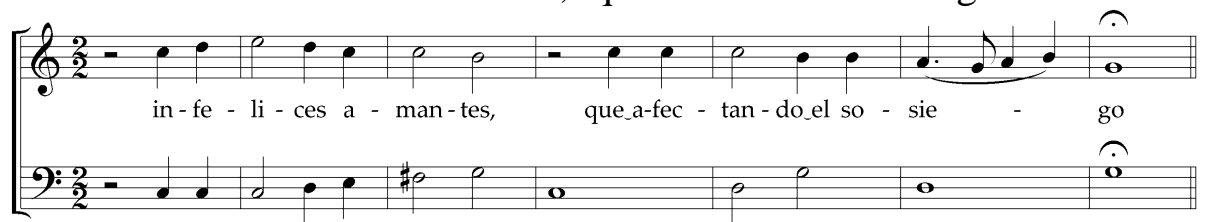

IPEM, p. 176.

Stein, p. 383.

${ }^{28}$ Merino Quijano. Op. cit., p. 110.

29 CABAllero FernándeZ-Rufete, Carmelo. «Nuevas fuentes musicales del teatro calderoniano». En: Revista de Musicología, XVI, 5 (1993), pp. 2965-2966 [Actas del XV Congreso de la Sociedad Internacional de Musicología. Madrid, 1992]. 
12. Abeja que al campo sales/ entre rosas y azucenas

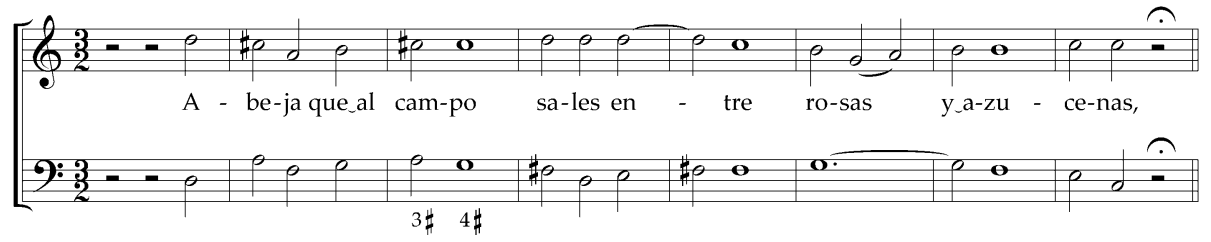

Cancionero Poético-Musical de Sutro, [n 17]. [Juan del] Vado

Transcripción paleográfica

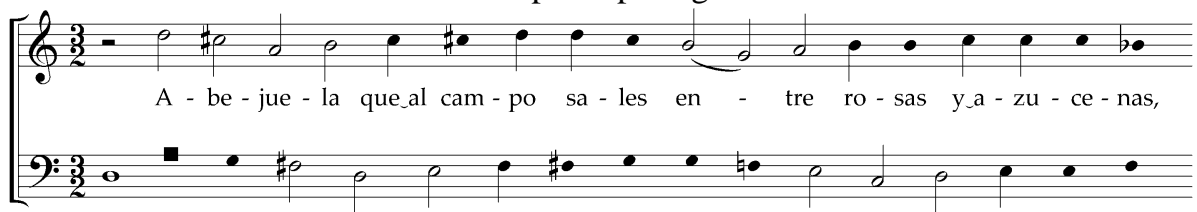
flores".

IPEM, p. 56; en la misma página consta también "Abejuela que buscas las

Sólo cambia la primera palabra del texto poético en ambas fuentes.

El estribillo de Juan del Vado perteneciente al Cancionero Poético-Musical de Sutro es intranscribible a notación moderna tal y como está ${ }^{30}$. Lo transcribimos paleográficamente para que el lector pueda observar las diferencias con el tono de la jácara.

En el tono «Zagala de Manzanares» (n 7), ya nos referimos al Ms. 4123. Volvemos de nuevo a él porque en el mismo Baile de la abejuela constan estos versos, quizá cantados y quién sabe si con la música de nuestro tono:

\section{Abejuela que al campo sales y entre rosas y azucenas buscas para tus colmenas lo dulce de tus panales etc. ${ }^{31}$.}

También citamos otra vez el Ms. 888 de la Biblioteca de Catalunya, de cuya confrontación con el tono de la jácara ha podido decir Valdivia: "Esta versión es también para voz solista y acompañamiento pero consta sólo de los dos primeros versos, los cuales se ajustan perfectamente a la cifra, con la única excepción de un do mayor que ésta indica en el $5^{\circ}$ compás, que no encaja con el acompañamiento pero sí con la melodía ${ }^{32}$."

13. Recibe, adorada ausente,/ estos suspiros cobardes

30 Signatura SMMS M1 de la Sutro Library en San Francisco (California). Agradecemos a Daniel Zuluaga el envío de una copia de este cancionero.

${ }^{31}$ Merino QuiJano. Op. cit., p. 229.

${ }^{32}$ VAldivia SEVILLA. Op. cit., p. 80. Cfr. YAKELEY. Op. cit., pp. 275-276. 


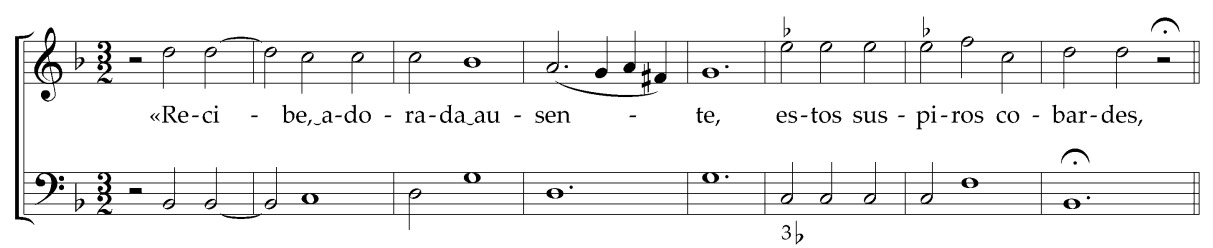

BN, Ms. 3881/35. [José] Marín

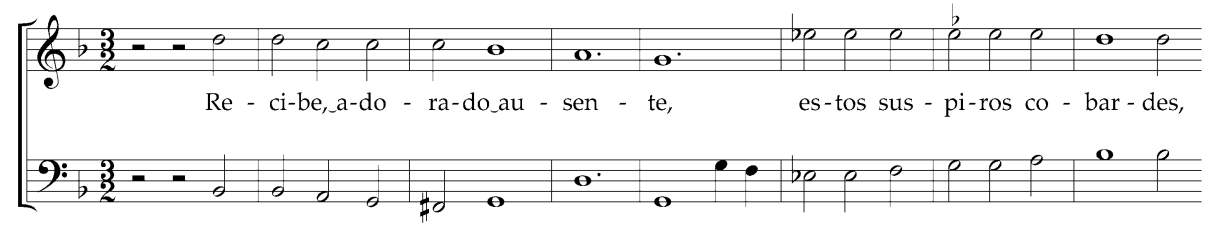

BC, M. 759/10. Anónimo

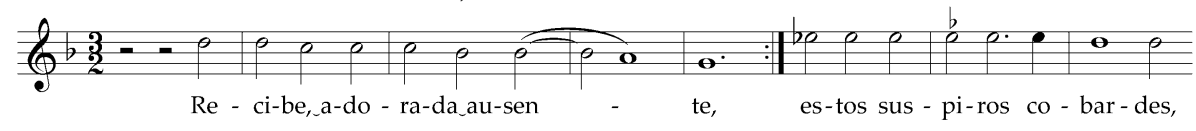

IPEM, p. 271.

Mínima diferencia en los textos poéticos.

Las diferencias musicales, rítmicas, melódicas y armónicas, son perceptibles en la jácara en relación con los otros dos testimonios, más parecidos entre sí.

Nota bene: Al término de nuestro trabajo no nos ha sido posible consultar el testimonio de la Biblioteca de Catalunya (M. 769/22, pp. 50-51).

14. Moradores de Roma,/ iparad, prestad atención!

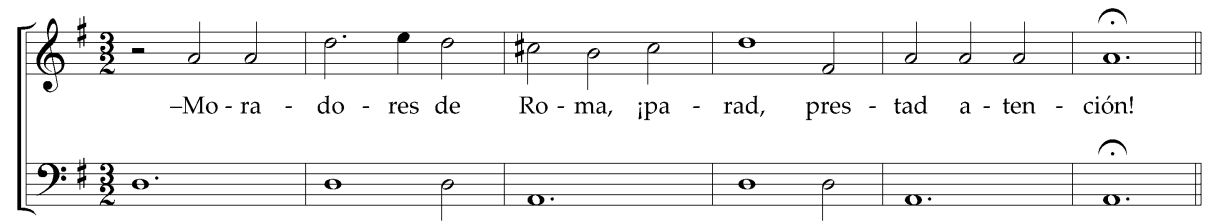

IPEM, p. 205.

Stein, p. 387.

De la confrontación del tono de la jácara con el Ms. 888 de la Biblioteca de Catalunya, dice Valdivia: "transportada una cuarta inferior, los acordes de los seis primeros compases - los únicos que recoge esta fuente- coinciden plenamente con las cifras del ms. $888^{33}$."

15. ¿No ves amar aquel risco/ aquella fuente, sin que...?

${ }^{33}$ Ibidem, p. 77. 


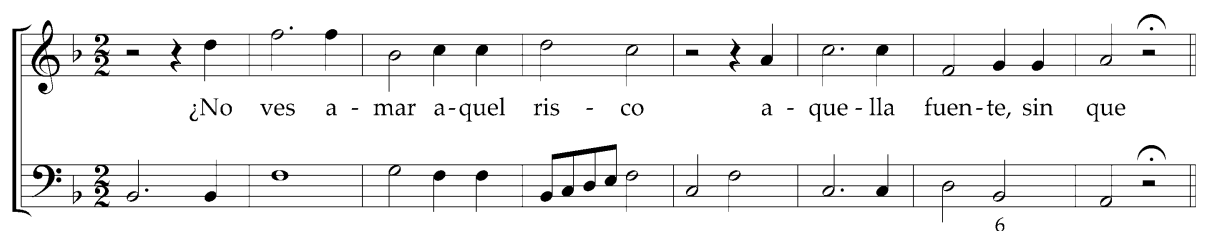

IPEM, p. 219.

Stein, pp. 388-389.

Como sucedía en el tono anterior, dice Valdivia: "comparando lo que nos ha transmitido esta fuente con las cifras del ms 888 resulta - una vez realizado el transporte necesario- que los acordes encajan bien con la melodía y que siguen, casi siempre, la misma armonía. Al menos en lo que respecta a los dos primeros versos ${ }^{34}$."

16. El curso transparente/ de su corriente clara

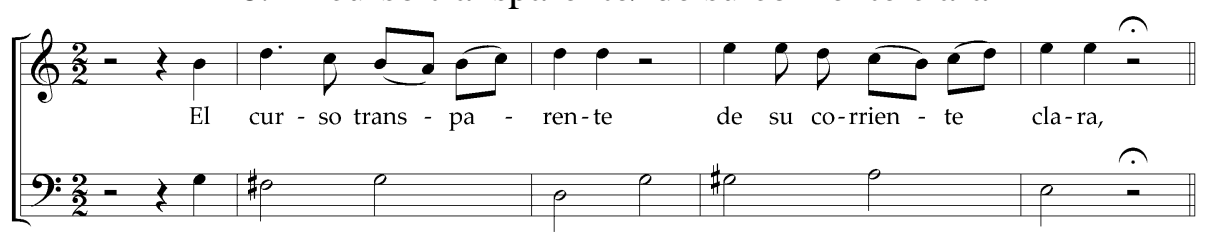

BC, M. 775/77[a]. Anónimo

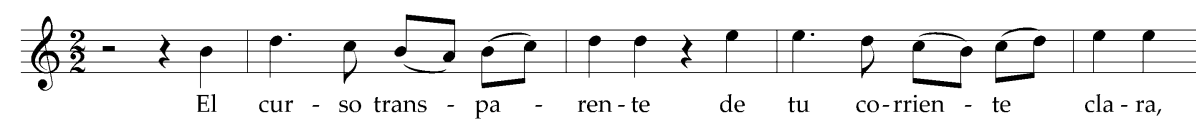

BC, M. 775/77[b]. Anónimo

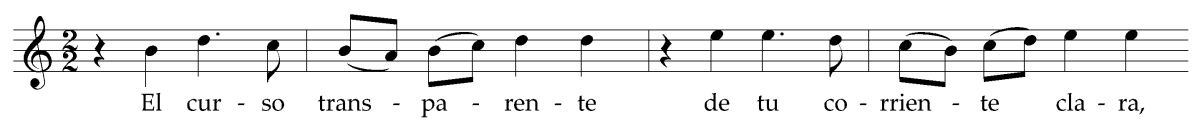

BC, M. 759/15. Anónimo

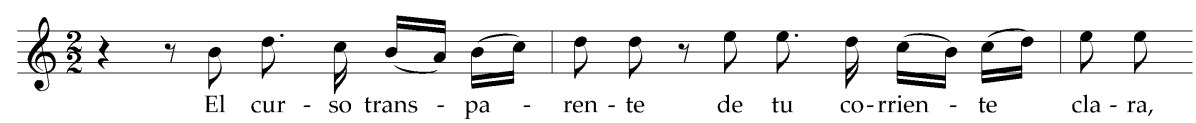

Libro de Tonos de José Miguel de Guerra, ff. 82v-83r. Anónimo

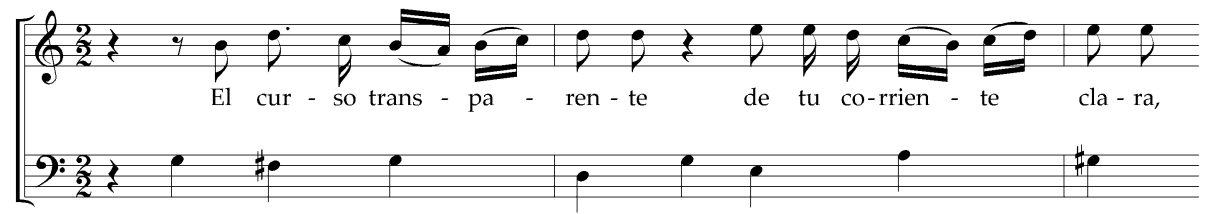

Archivo de la Catedral de Burgos, BU 61/22. Juan Hidalgo De la transcripción de P. García Garmilla

${ }^{34}$ Ibidem, p. 68. 


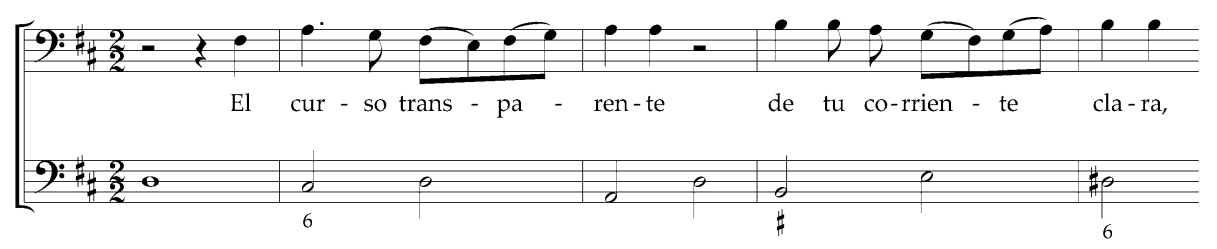

BN, Ms. 13622, f. 113r. Anónimo

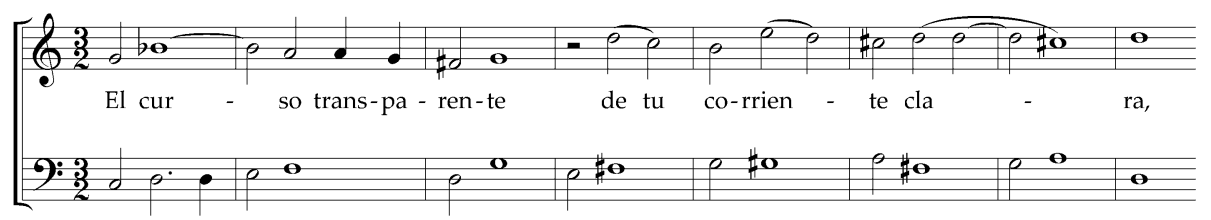

IPEM, p. 140.

Stein, p. 376.

Torrente y Rodríguez ${ }^{35}$.

García Garmilla ${ }^{36}$.

Caballero, p. $237^{37}$.

Las diferencias en los textos poéticos son mínimas.

Como podrá observar el lector las versiones musicales de este tono son numerosas. Todas se parecen mucho entre sí, siendo la de la Biblioteca Nacional (Ms. 13622 [Manuscrito Gayangos-Barbieri]) la que se desmarca de la afinidad general.

Carmelo Caballero nos comunica la existencia de otra versión de esta pieza en el Archivo de la Catedral de Valladolid que, al término de nuestro trabajo no nos ha sido posible consultar. La referencia que nos da tan amablemente nuestro colega es la siguiente: La música en la Iglesia de Castilla y León. Polifonía y órgano. Valladolid: Las Edades del Hombre, 1991, pp. 362-364 (transcripción) y 312-314 (comentarios).

17. Don Pedro a quien los crueles/ llaman, sin razón, cruel

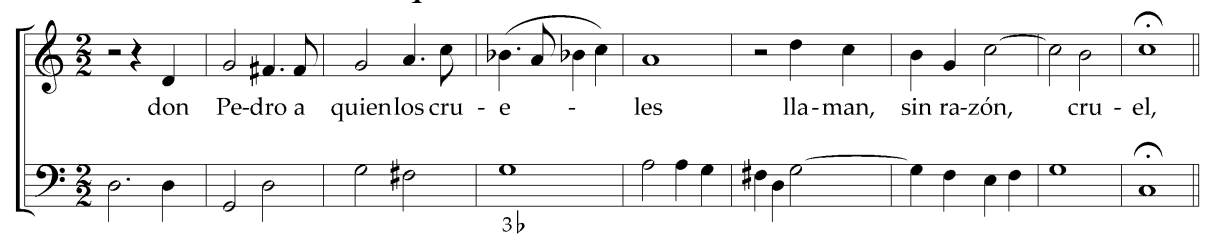

${ }^{35}$ Véase TORREnTE, Álvaro y RodríGueZ, Pablo-L. «The 'Guerra Manuscript' (c. 1680) and the Rise of Solo Song in Spain». En: Journal of the Royal Musical Association, 123, 2 (1998), p. 184. Mencionan los autores la existencia de una versión a lo divino de este tono en el Archivo de la Catedral de Segovia. Consultado el catálogo correspondiente viene ahí formando parte de «Cielos, astros, signos» "Solo a Nuestra Señora", 46/15, de Juan Hidalgo, con la misma música de «Peces, fieras, aves» (véase López-Calo, José. La música en la Catedral de Segovia. Catálogo del Archivo de Música. Segovia: Diputación Provincial de Segovia, 1989, vol. II, p. 264). Nos abstenemos de perder el tiempo pidiendo una copia de este tono al Cabildo ante el fracaso de un pedido anterior que ni siquiera mereció contestación por su parte (véase JosA, Lola y LAMBEA, Mariano (eds.). Manojuelo Poético-Musical de Nueva York (The Hispanic Society of America). Madrid: CSIC, 2008, p. 64b.

${ }^{36}$ García Garmilla, Patxi. Música a lo divino y a lo humano. 141 obras del Archivo de la Catedral de Burgos (siglos XVII y XVIII). Catedral de Burgos / Aula Boreal, 2008, pp. 61-62.

37 Véase CABALleRo, Carmelo. «El manuscrito Gayangos-Barbieri». En: Revista de Musicología, XII, 1 (1989), p. 237. 
Cancionero Poético-Musical de Gregorio Dezuola [n 13]. Anónimo

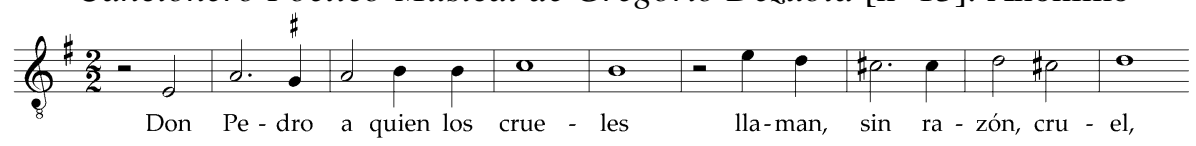

Manuscrito Novena, p. 106. Anónimo

Museo Nacional del Teatro (Almagro)

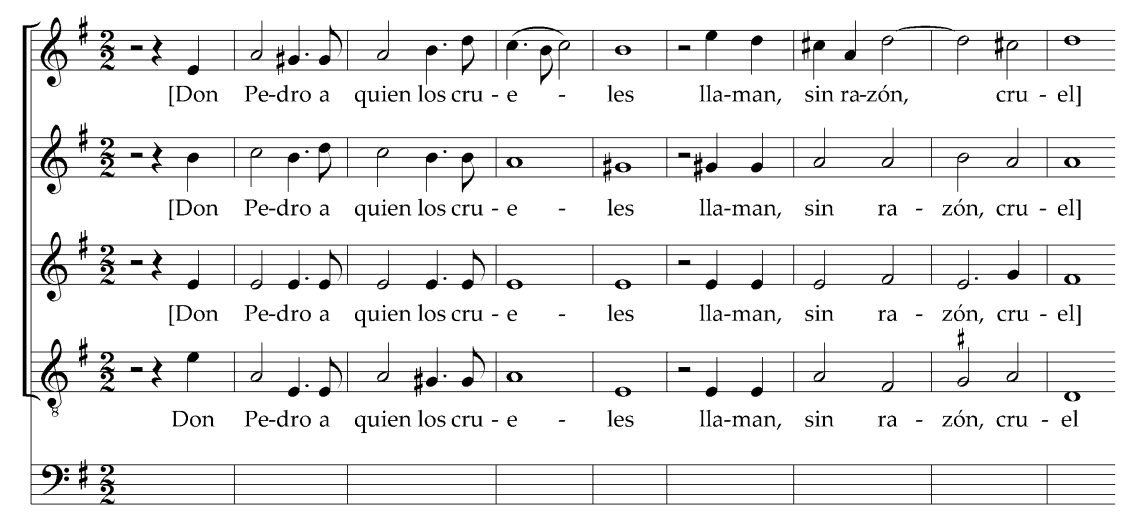

Manuscrito Novena, p. 106. Anónimo

Museo Nacional del Teatro (Almagro)

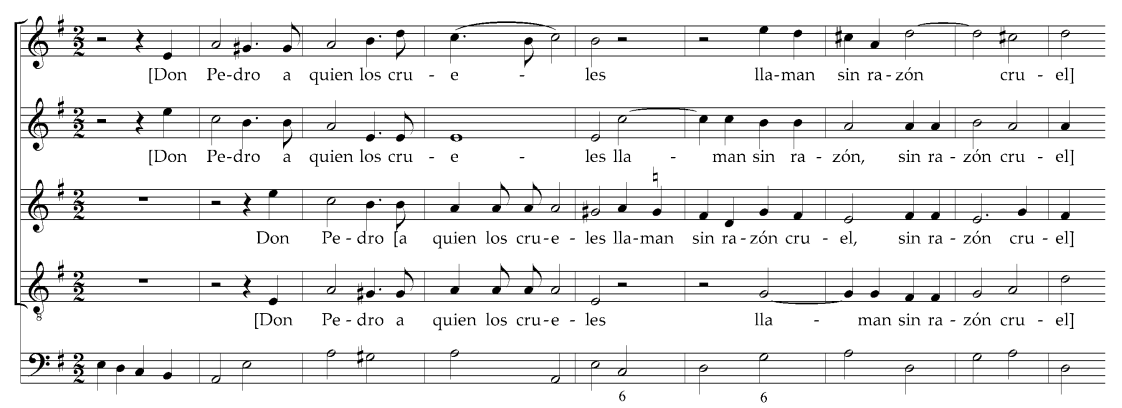

BN, Ms. 13622, f. 211r. Anónimo

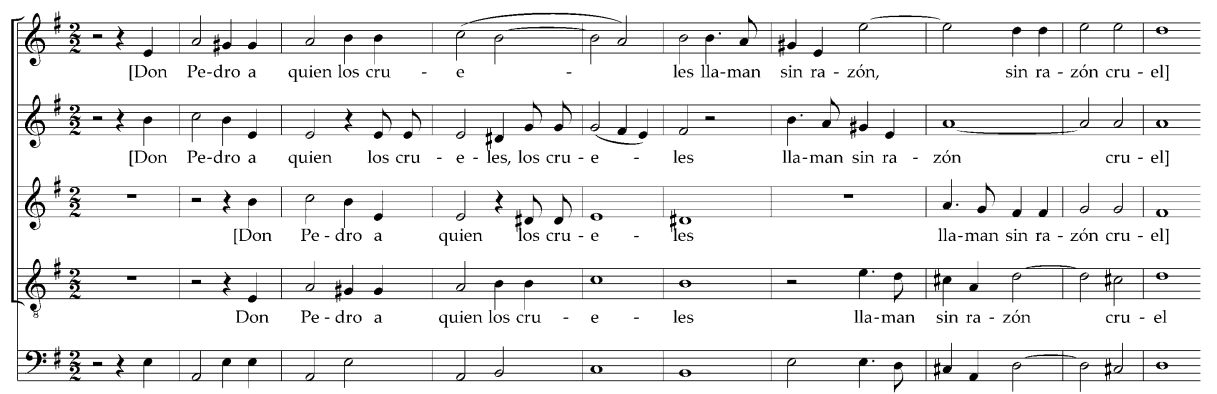

IPEM, p. 134.

Stein, p. 376.

El Cancionero Poético-Musical de Gregorio Dezuola se conserva en el Convento de San Francisco, en Cuzco (Perú) ${ }^{38}$.

${ }^{38}$ Véase VEGA, Carlos. La música de un códice colonial del siglo XVII. Buenos Aires: Imprenta de la Universidad, 1931, p. 79. 
Caballero, p. $256^{39}$.

No hay ninguna variante en los textos poéticos.

Sin duda, lo más interesante para nosotros son las tres versiones polifónicas de la melodía principal, y de ellas, especialmente, las dos armonizaciones del Manuscrito Novena, las cuales nos permiten observar los diferentes planteamientos del anónimo compositor.

La transcripción de la versión de la Biblioteca Nacional (Ms. 13622 [Manuscrito Gayangos-Barbieri]) ha presentado ciertas dificultades, por descuidos del copista, que hemos intentado resolver lo mejor posible.

18. ¡Bárbaros moradores de Anoia,/ suspended, parad, despedid!

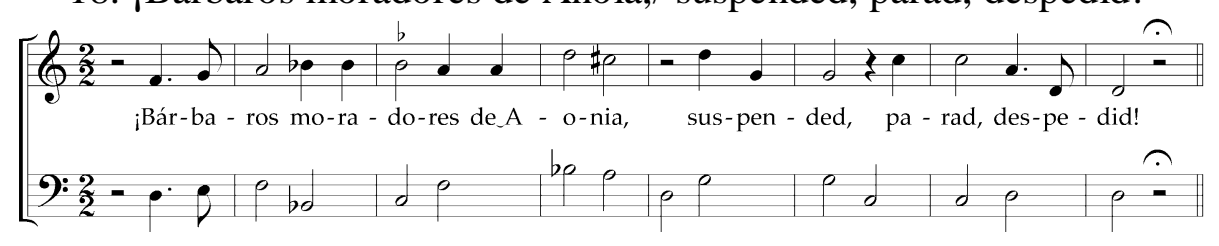

Cancionero Poético-Musical de Sutro, [n $\left.{ }^{\circ} 46\right]$. [Juan Francisco de] Navas

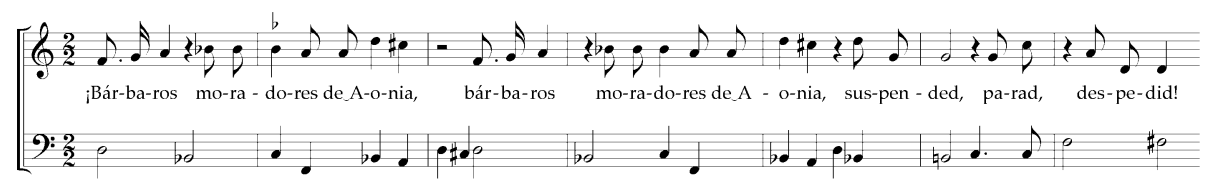

IPEM, p. 89.

No hay diferencias en el texto.

La confrontación de ambas fuentes nos ofrece detalles interesantes: así, el testimonio de Sutro repite el texto, su bajo acompañante es diferente al de la jácara y los cromatismos de los compases 5/6 y 7 son también dignos de mención.

19. Aglauros, infelice,/ que del sueño te vences

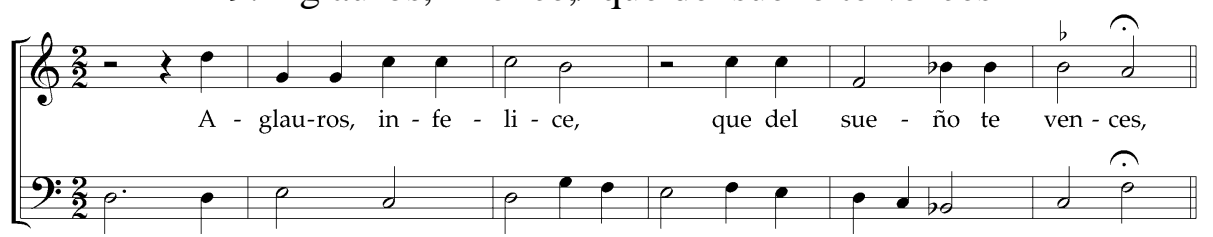

IPEM, pp. 52 y 59.

Ante todo, lo que nos interesa constatar de este tono es la oscilación de su primera palabra: “"Aglauros" o "Glauros"? En diversas fuentes aparece indistintamente, aunque la tradición reconoce dos Aglauros, madre e hija ${ }^{40}$.

$\mathrm{Al}$ igual que el tono «La beldad que en la pura» $\left(\mathrm{n}^{\circ} 4\right)$, el que ahora comentamos también se halla entre las poesías sin música del Ms. 2478 de la Biblioteca Nacional ${ }^{41}$.

\footnotetext{
${ }^{39}$ Véase CABALLERO. «El manuscrito...»», p. 256 (consta Latorre).

40 Véase Grimal, Pierre. Diccionario de mitología griega y romana. Barcelona: Ediciones Paidós, 1993, entrada «Aglauro».
} 
20. A las doce va por agua/ la zangarilleja
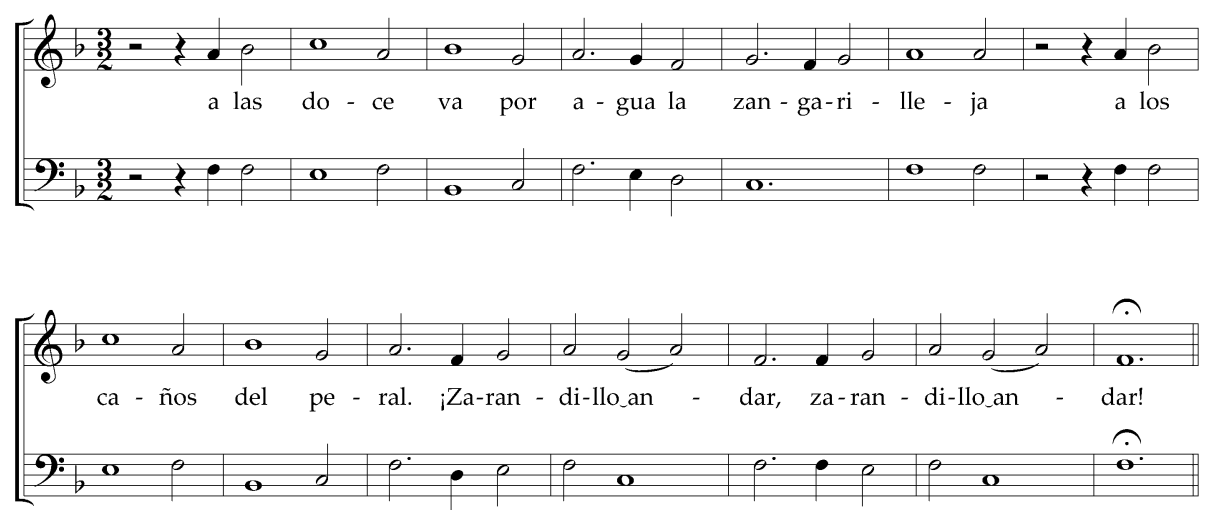

Las tonadillas antiguas. José Martínez de Arce

De la transcripción de C. Caballero

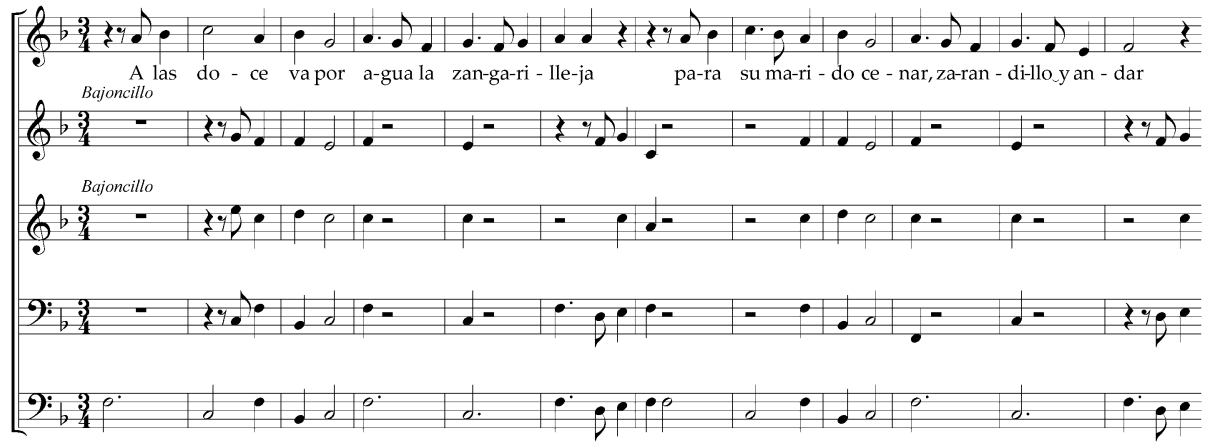

Las variantes entre los textos poéticos de ambas fuentes afectan principalmente al tercer verso.

También hay diferencias musicales interesantes, tanto a nivel melódico como $\operatorname{armónico~}^{42}$.

${ }^{41}$ Véase GoldBerg. Op. cit., p. 29.

${ }^{42}$ Debemos a Carmelo Caballero el conocimiento de la versión musical de Martínez de Arce, y le agradecemos aquí su amabilidad al facilitarnos su transcripción de la misma. Citamos algunas de sus palabras sobre esta pieza por su evidente interés "El villancico Las tonadillas antiguas, de José Martínez de Arce, significativamente subtitulado en la fuente manuscrita "Villancico del Alcalde" [...] se sitúa justo en el límite cronológico que estamos considerando, puesto que data de 1699 [...]. Presenta numerosos puntos de contacto con el teatro breve en general y más particularmente con la mojiganga [...] Nuestro interés en este momento se centra, como hemos dicho, en la utilización de citas completas de cuatro tonos, supuestamente de aquellos 'conocidamente profanos' y 'babeados por las calles y plazas'. En concreto, las melodías utilizadas son: la Zangarilleja, Marizápalos, el Triste de Jorge y El derrengado Bartolomé. Las levísimas alteraciones detectadas en los textos no tienen, desde luego, un propósito sacralizador; antes bien, son recursos para dinamizar el diálogo entre los personajes del villancico (por tanto, se trata de modificaciones con un propósito 'quasi-dramático'). La melodía se presenta en su forma original, aunque fueron añadidos - parece ser que de forma opcional, a la luz de las diferentes versiones conservadas- unos bajoncillos que ni modifican ni ocultan la melodía del tono" (CABALLERO. «Miscent sacra profanis...», p. 56). Lamentablemente la versión completa de Las tonadillas antiguas y otros villancicos más de Martínez de Arce, permanecen inéditos a pesar de estar dispuestos para su edición por nuestro colega. 
De la popularidad en su tiempo de la cancioncilla o copla de la zangarilleja da fe el Diccionario de Autoridades, que la refiere como "copla vulgar" y en cuya respectiva entrada incluye, curiosamente, el texto del tono de la jácara con una variante en su primer verso: "Zangarilleja, la muchacha o moza puerca y mal vestida, que anda vagando [...]. A la fuente va por agual la zangarilleja/ a los caños del peral/ zarandillo andar" (Aut.).

Ángel González Palencia publicó el texto (200 versos) de la “Tonadilla y xácara nueva de la «Zangarilleja, çarandillo andar», que oy está tan valida en la corte, con los chistes, pasatiempos y conceptos, novedades y chança que requiere el buen gusto, compuesta por el doctor Modorro, examinador de toda picaresca y marcador de todo cuartillo", impresa en Madrid, en 1683, ofreciendo datos sobre su inclusión en diversas obras escénicas ${ }^{43}$.

Alonso de Ayala, en su Mojiganga para la zarzuela de "Quinto elemento es amor", intercaló versos de la copla de la zangarilleja, sin que podamos saber, por la acotación, si serían cantados o no, ya que en ella sólo consta la indicación "los 4" que son "Alfeo, Aretusa, Hércules y Eco". Catalina Buezo, editora de la mojiganga, no deja de referir que "contravenía las reglas del decoro poner en boca de personajes elevados la cancioncilla de la zangarilleja ${ }^{44}$."

Otras fuentes literarias de la copla de la zangarilleja son citadas por Margit Frenk en su imprescindible Corpus $^{45}$.
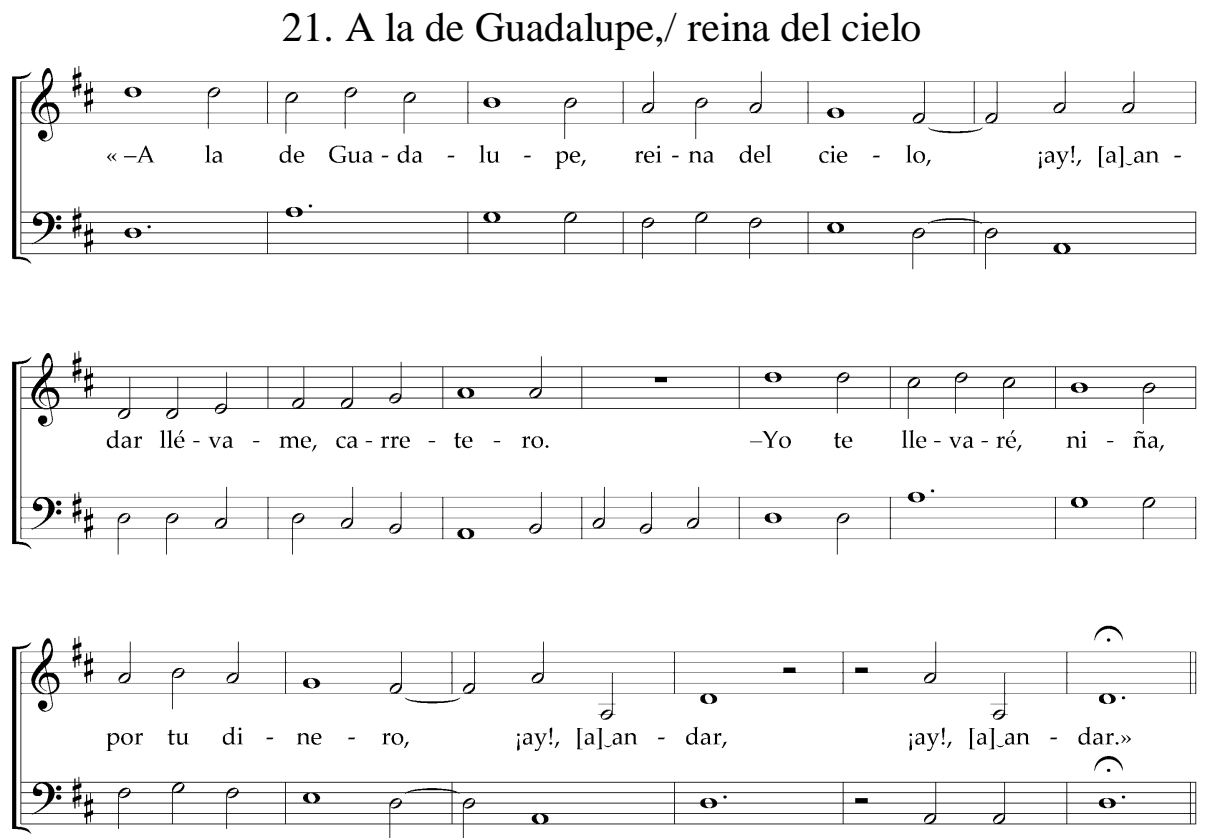

No hemos hallado ninguna fuente poético-musical de este tono.

${ }^{43}$ Véase GONZÁLEZ PALENCIA, Ángel. La zangarilleja (tonadilla y jácara del siglo XVII). Tirada aparte de la Revista de la Biblioteca, Archivo y Museo del Ayuntamiento de Madrid. Madrid: Imprenta Municipal, 1925, 11 pp.

44 Buezo, Catalina (ed.). La mojiganga dramática. De la fiesta al teatro. Kassel: Edition Reichenberger, 2005, pp. 360-370.

45 FRENK, Margit. Nuevo corpus de la antigua lírica popular hispánica (siglos XV a XVII). México: Universidad Nacional Autónoma de México. El Colegio de México. Fondo de Cultura Económica, 2003, vol. II, pp. 1124-1125. 
Nota bene: Se ofrecen dos transcripciones completas de la jácara a notación moderna. Una con los correspondientes íncipits y otra, más práctica, sin ellos, pensada para una posible interpretación.

Por último, incluimos el facsímil de la Jácara con variedad de tonos, haciendo constar nuestro agradecimiento a la Biblioteca de Catalunya por las facilidades otorgadas para su publicación. 


\section{Jácara con variedad de tonos}

Música: Anónimo. Letra: Anónimo

Biblioteca de Catalunya

M. 753/24
Transcripción poético-musical: Mariano Lambea \& Lola Josa

¡Jácara-dijo Andresillo-,

aunque sea a troche y moche!:

[Tiple]

1.

[Acompañamiento]
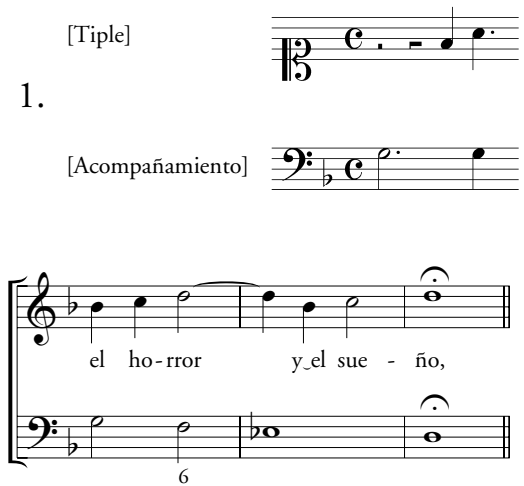

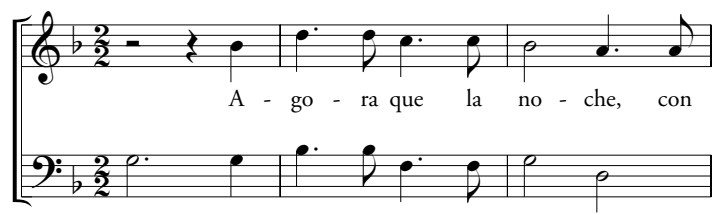

quitando a la muerte el ceño, inviar a los hombres quiso

2.
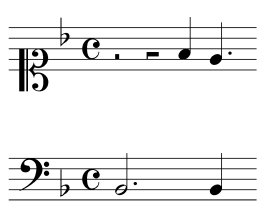
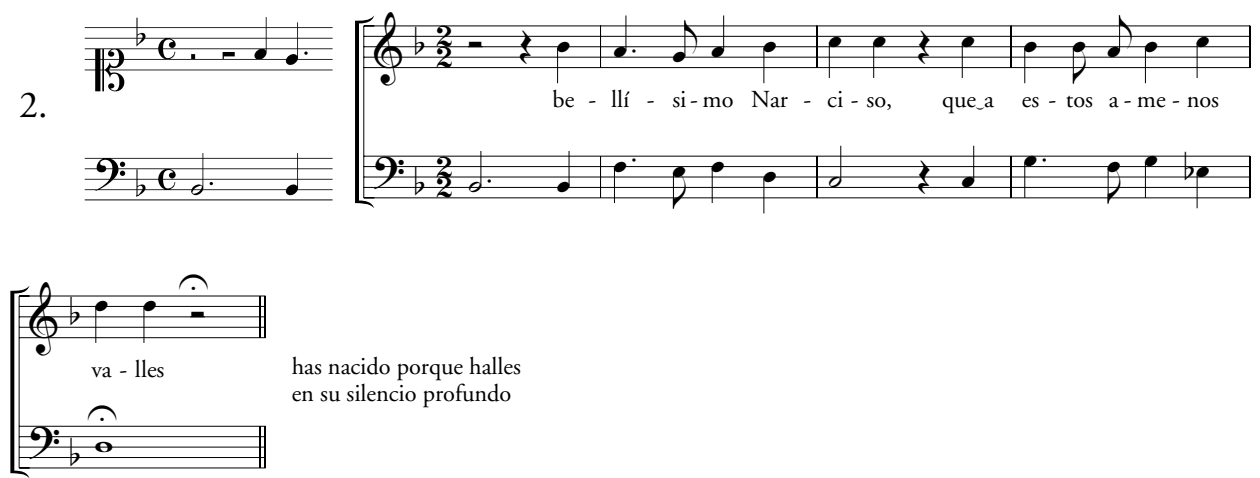

has nacido porque halles en su silencio profundo

3.

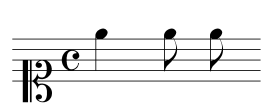

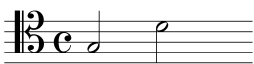

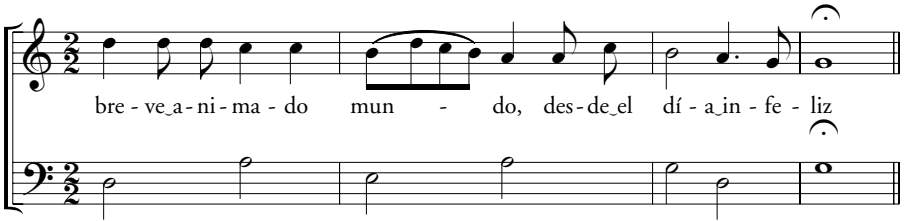

para la mortal cerviz

que labra nuestra ventura; 
4.

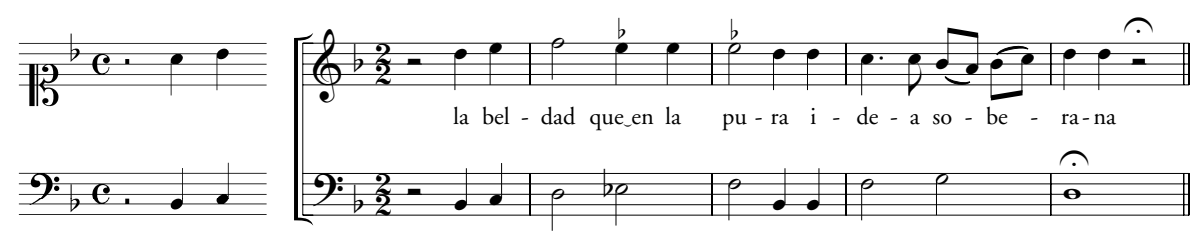

se escogió para que ufana

le diese al demonio un chasco

5.
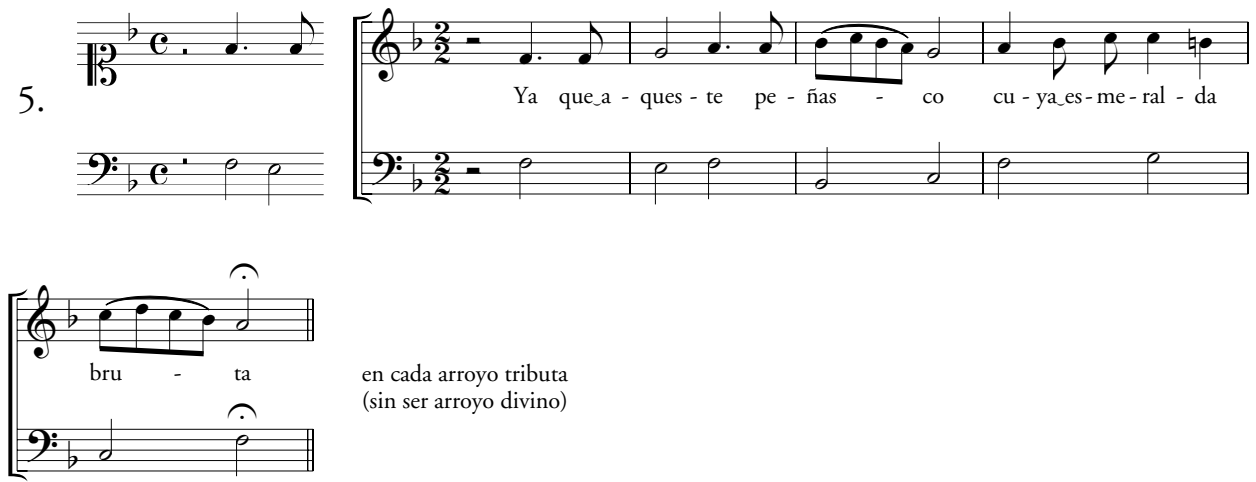

en cada arroyo tributa (sin ser arroyo divino)

6.
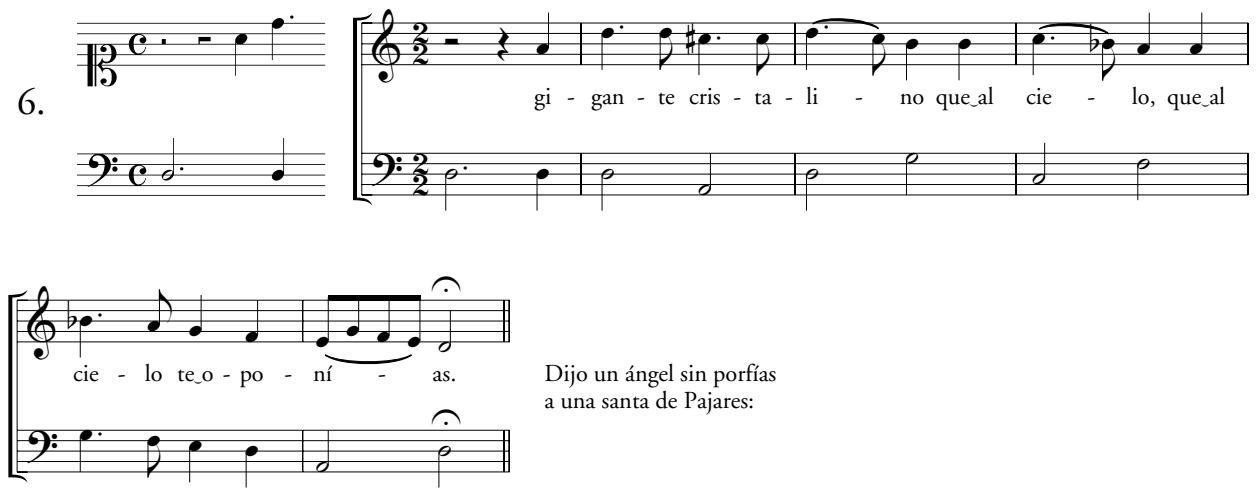

Dijo un ángel sin porfías a una santa de Pajares:

7.
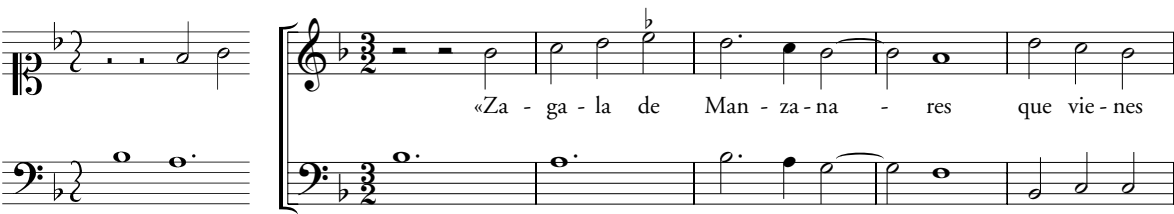


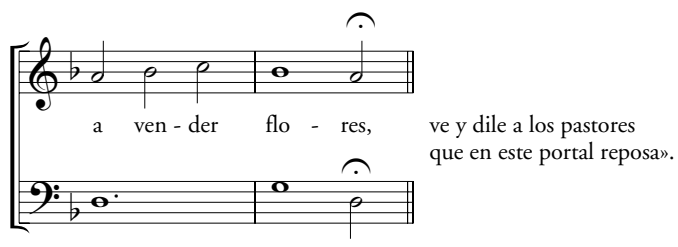

8.
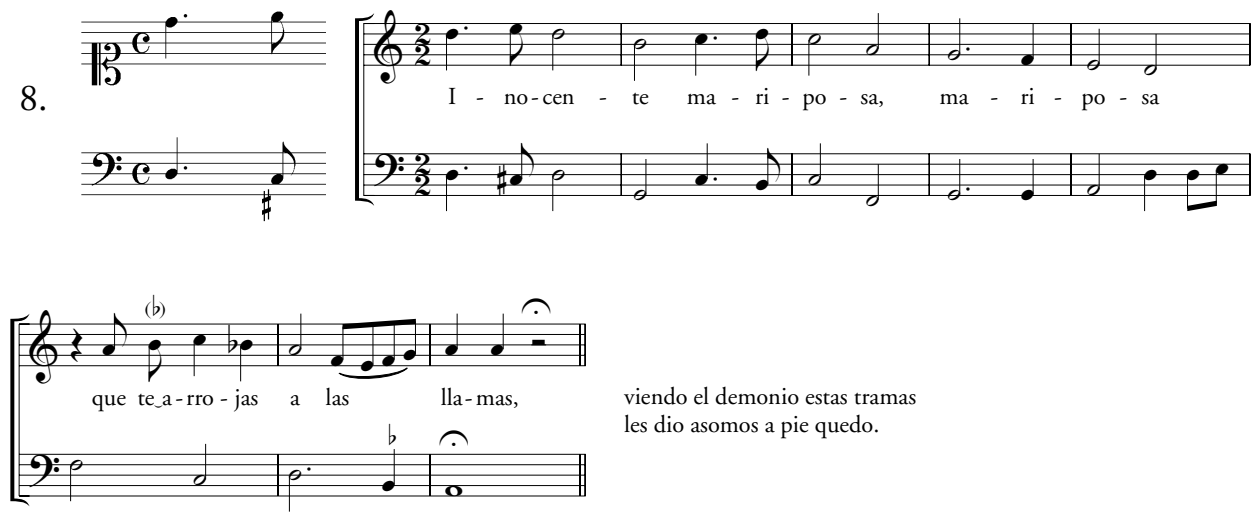

viendo el demonio estas tramas les dio asomos a pie quedo.

9.
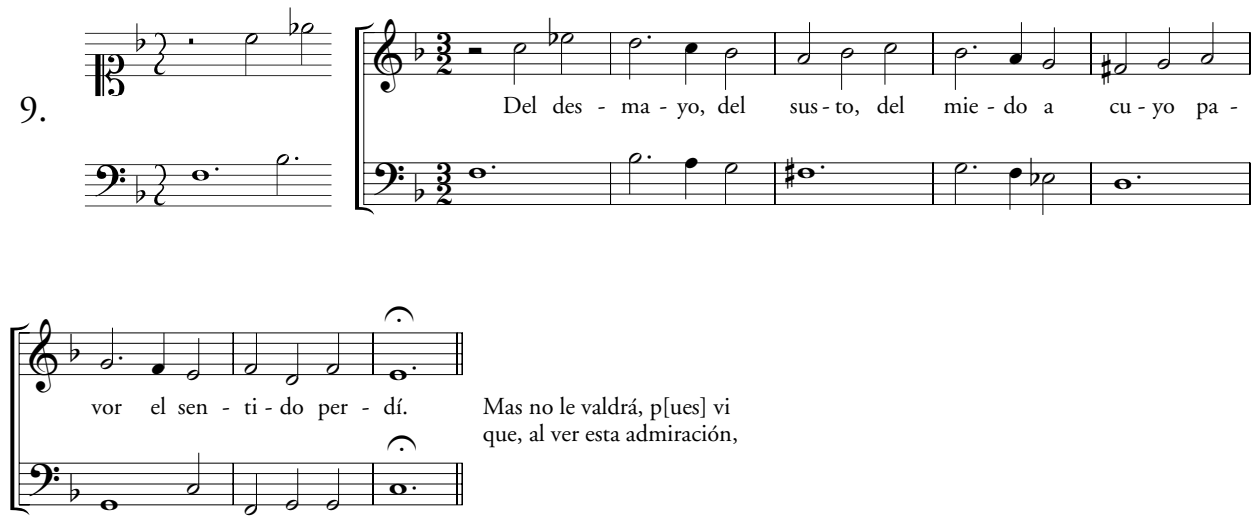

10.

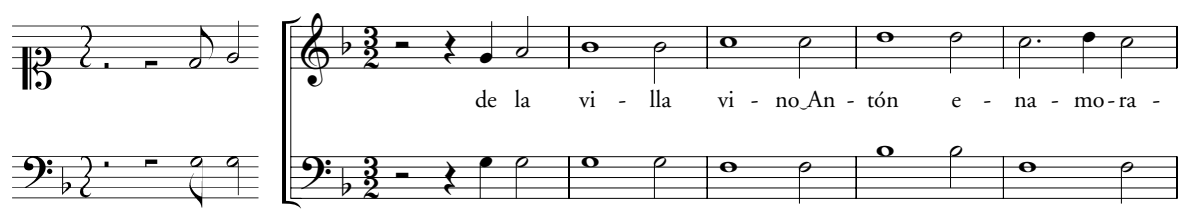




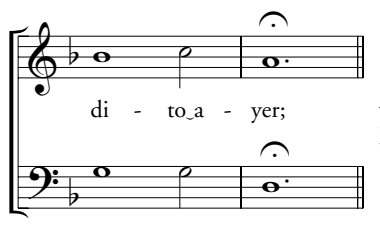

vino Gil y su mujer

los que fueron ahora $y$ antes

11.
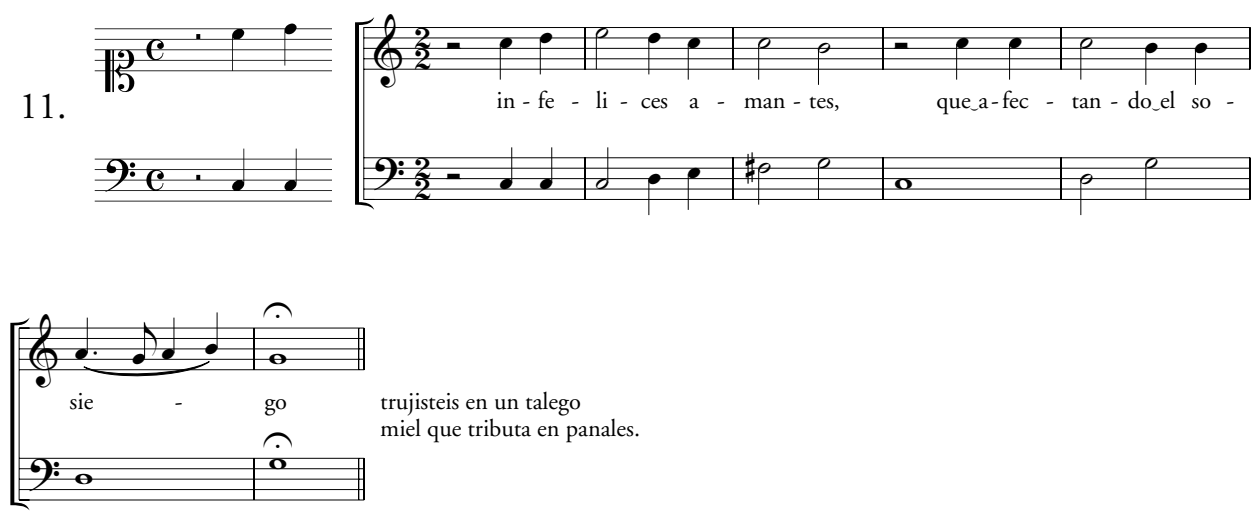

12.
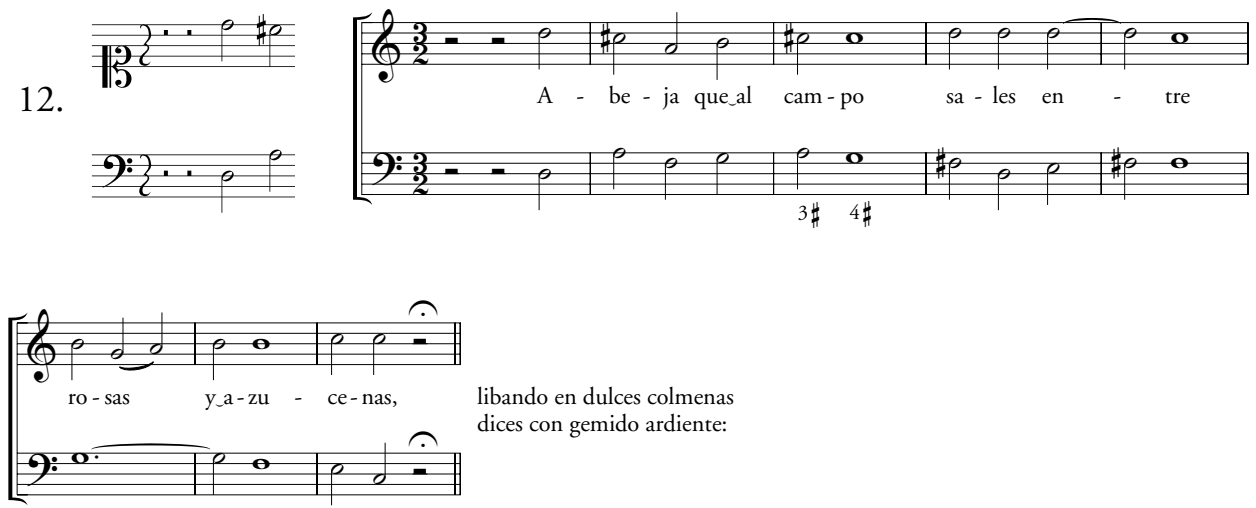

13.
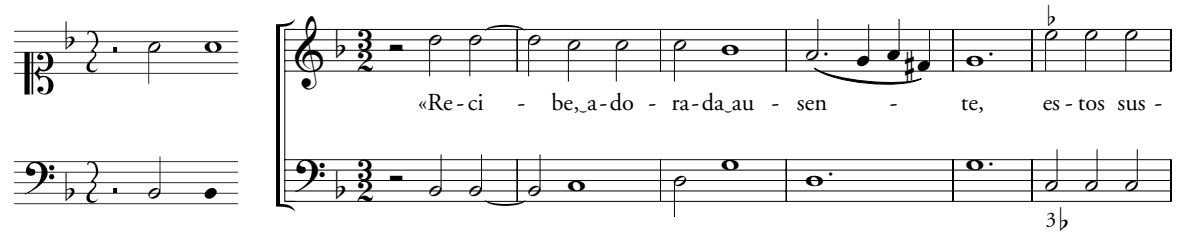


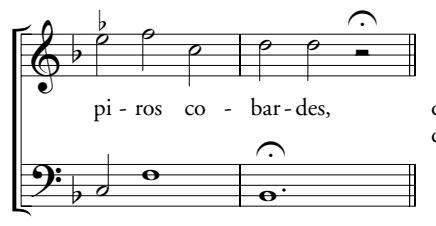

que antes de cincuenta tardes dirán tres reyes de edad:

14.
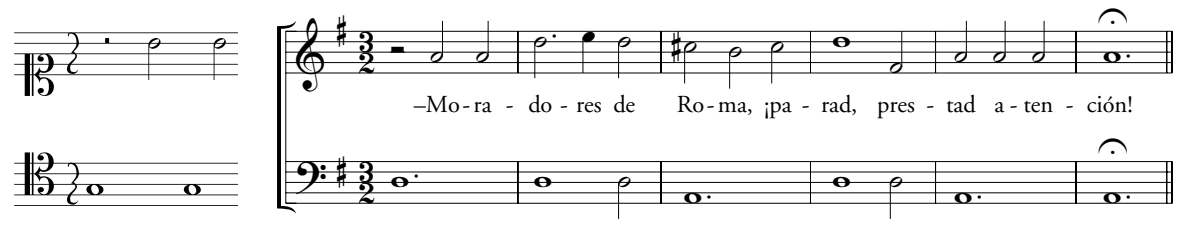

Y uno, por más devoción,

trae su máscara de cisco".

15.
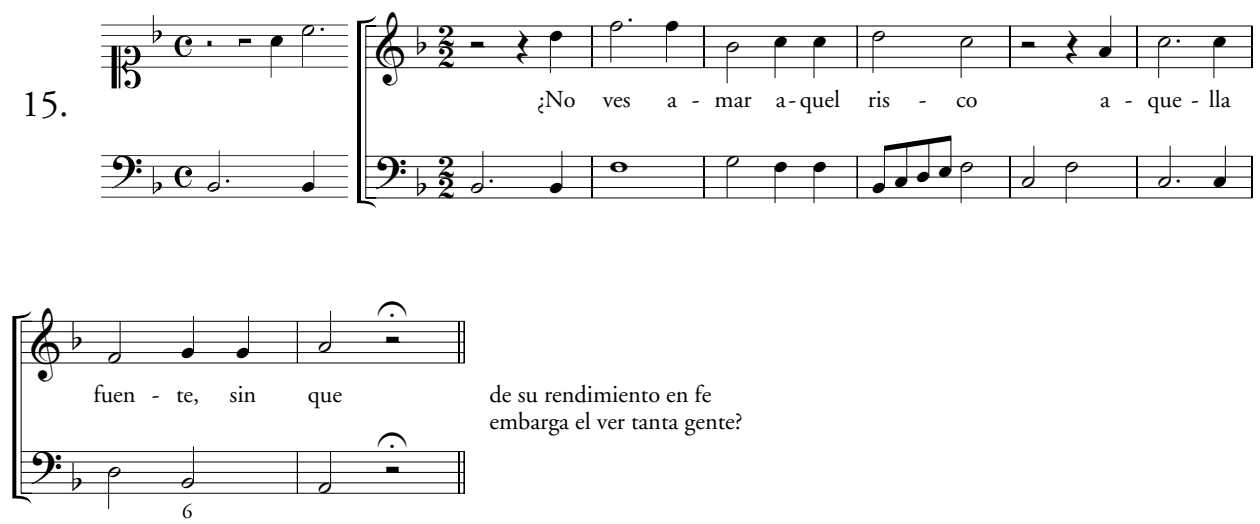

16.
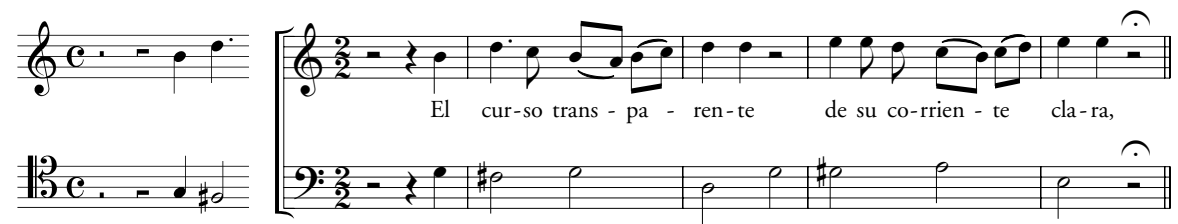

cuando al infante prepara cogerle con sus infieles, 
17.
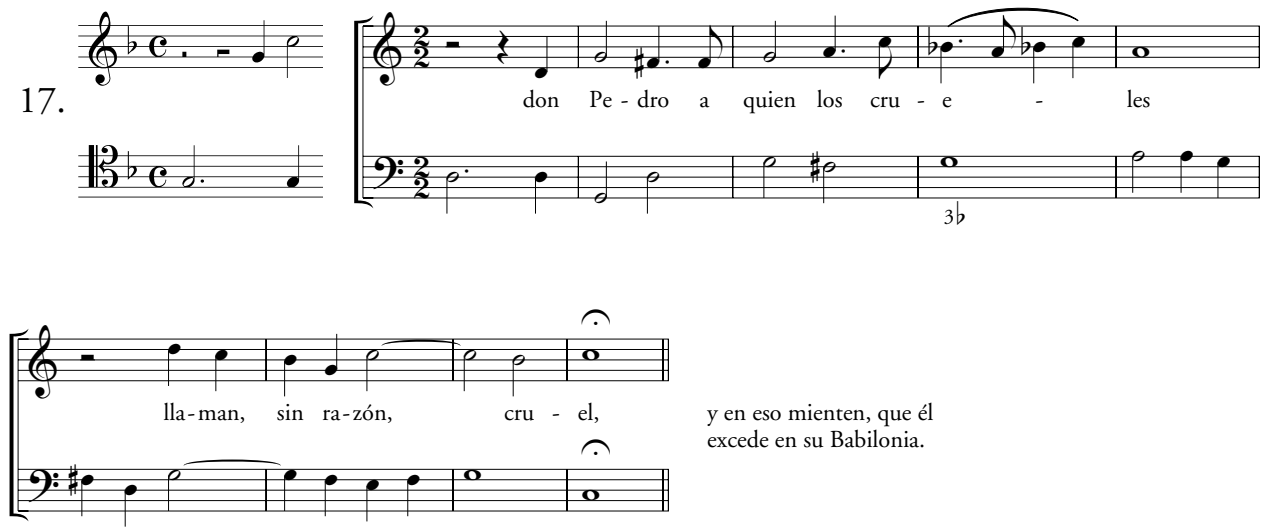

y en eso mienten, que é excede en su Babilonia.

18.
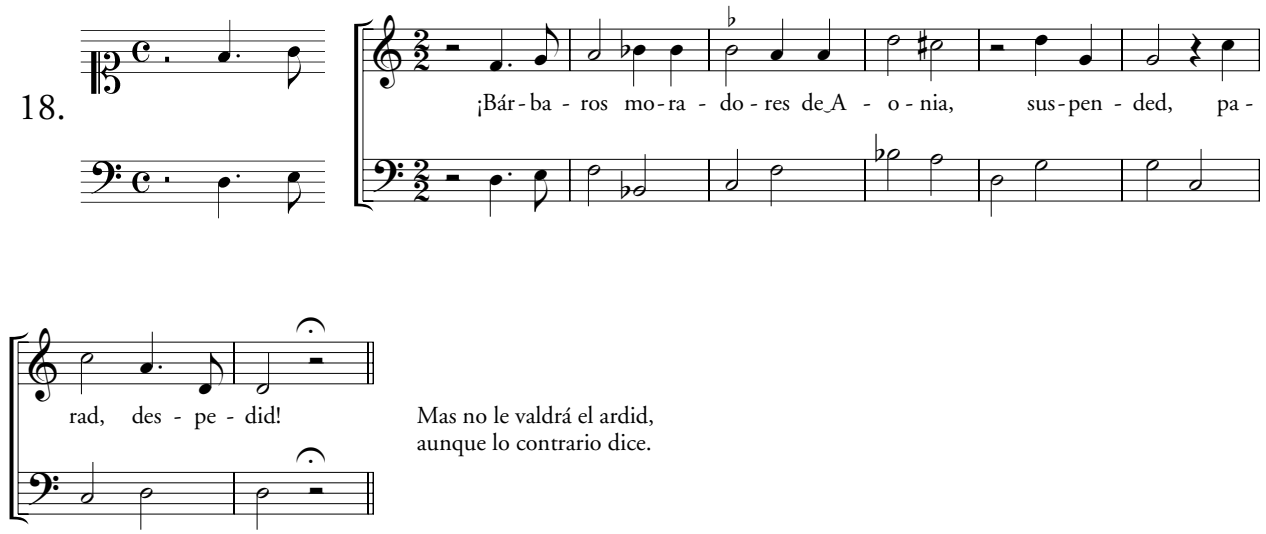

Mas no le valdrá el ardid, aunque lo contrario dice.

19.
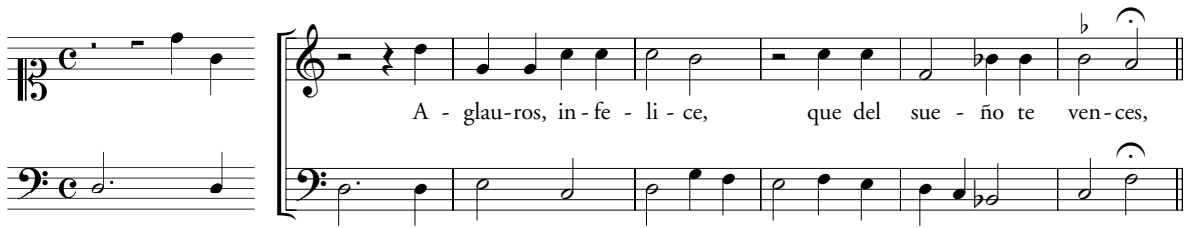

y aunque sepas más vascuences

que la tonada que fragua,

20.
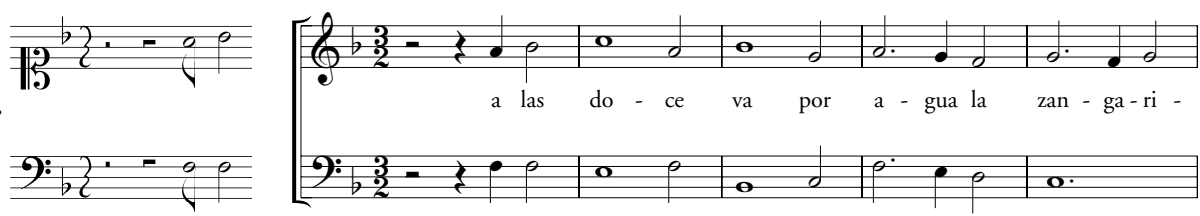


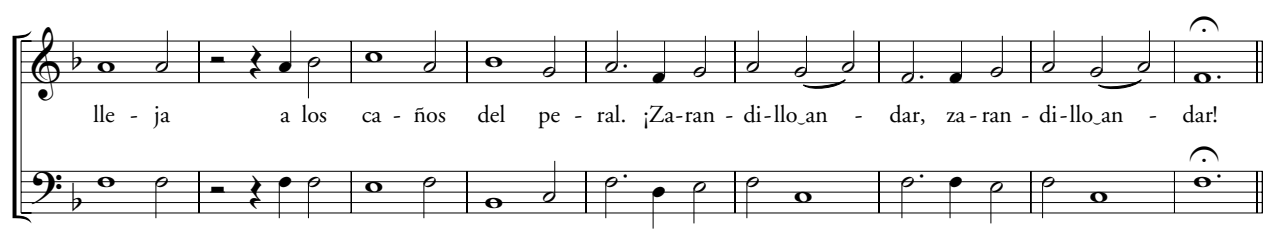

- Y acaba de par en par, musa que tonos escupe:

21.
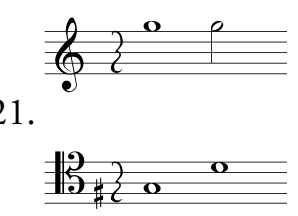

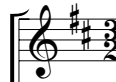

2: 3
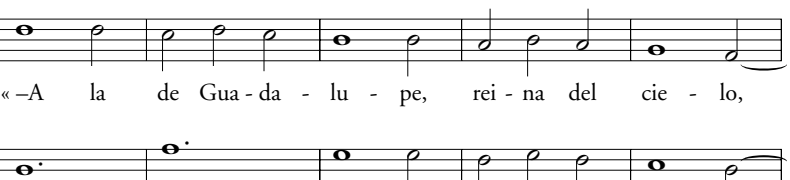

$\mathbf{\theta}^{\circ}$

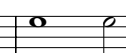

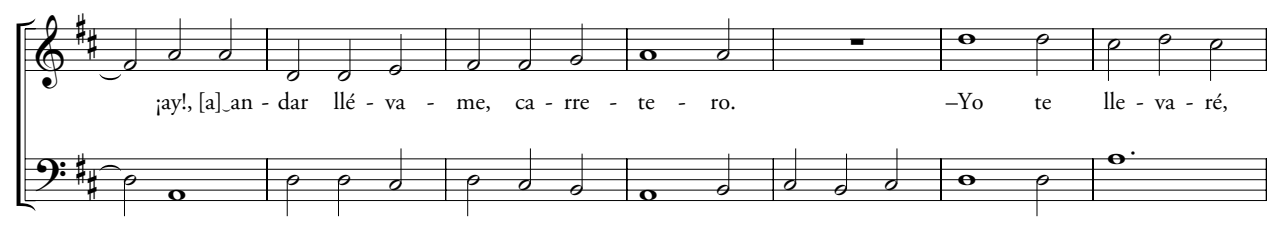

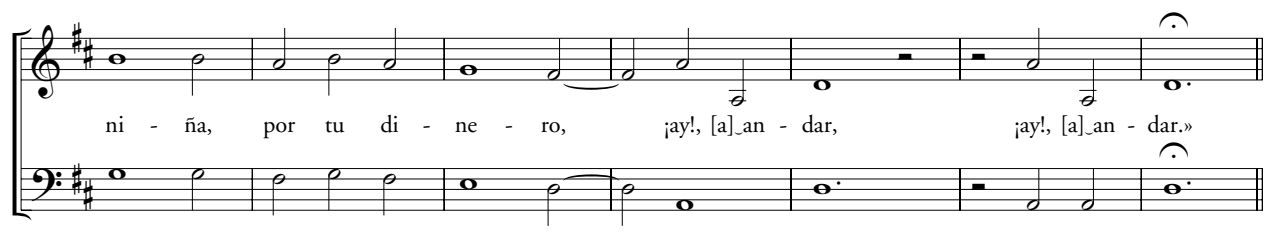




\title{
Jácara con variedad de tonos
}

\author{
Música: Anónimo. Letra: Anónimo
}

Biblioteca de Catalunya

M. $753 / 24$
Transcripción poético-musical: Mariano Lambea \& Lola Josa

¡Jácara-dijo Andresillo-,

aunque sea a troche y moche!:

[Tiple]

1.

[Acompañamiento]

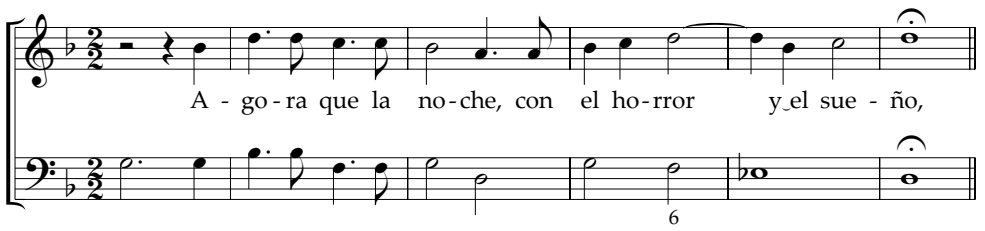

quitando a la muerte el ceño,

inviar a los hombres quiso

2.

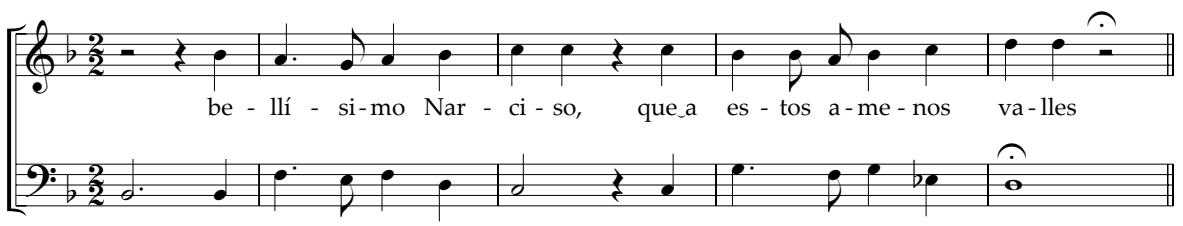

has nacido porque halles

en su silencio profundo

3.

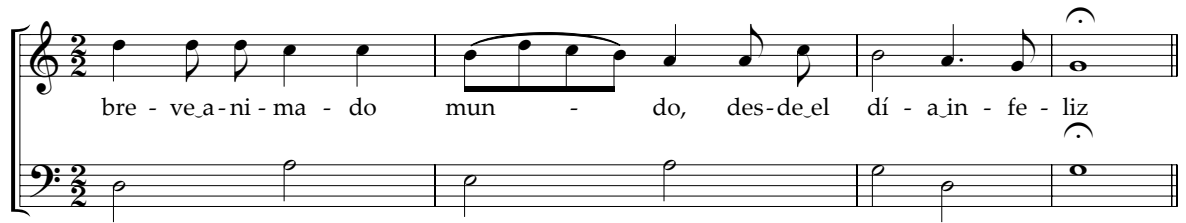

para la mortal cerviz

que labra nuestra ventura;

4.

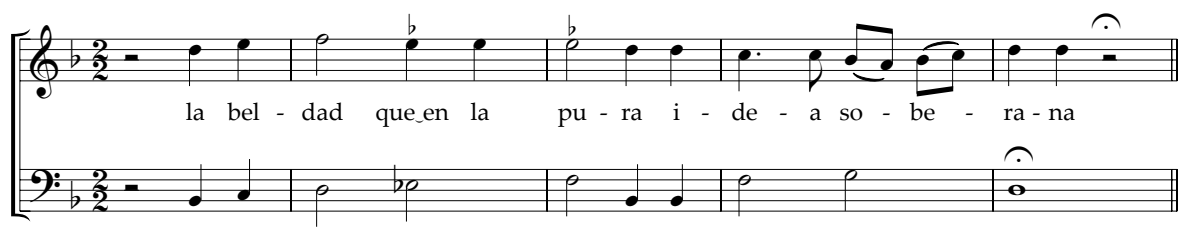


se escogió para que ufana

le diese al demonio un chasco

5.

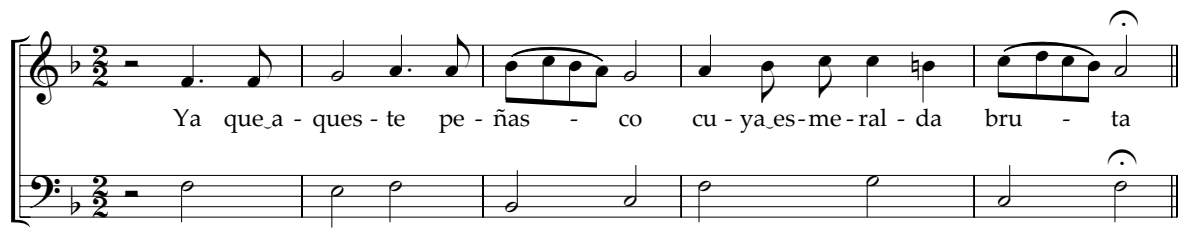

en cada arroyo tributa

(sin ser arroyo divino)

6.

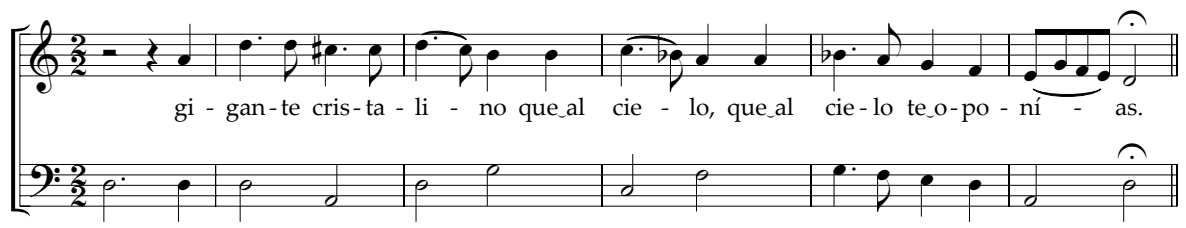

Dijo un ángel sin porfías

a una santa de Pajares:

7.

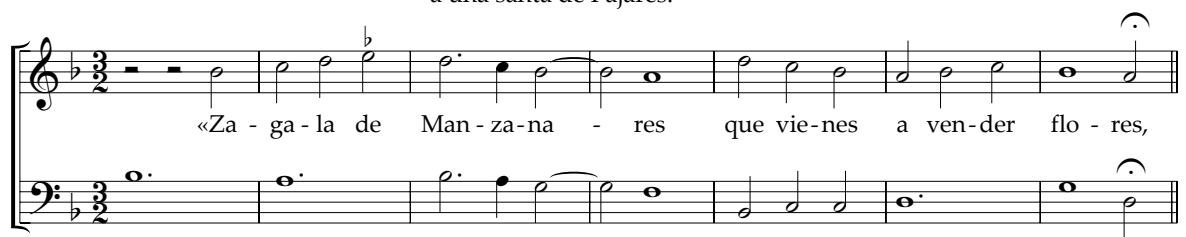

ve y dile a los pastores

que en este portal reposa».

8.

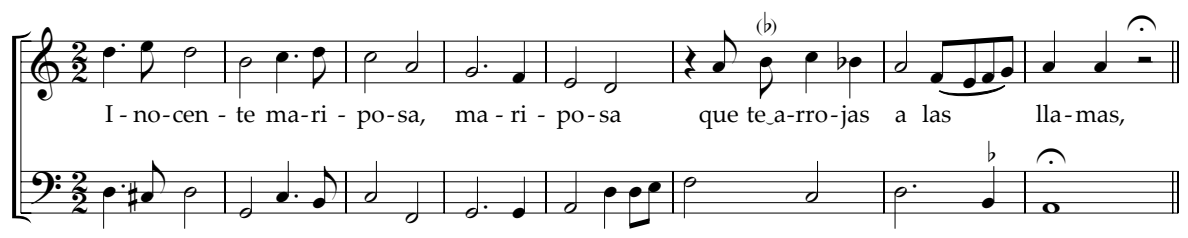

viendo el demonio estas tramas

les dio asomos a pie quedo.

9.

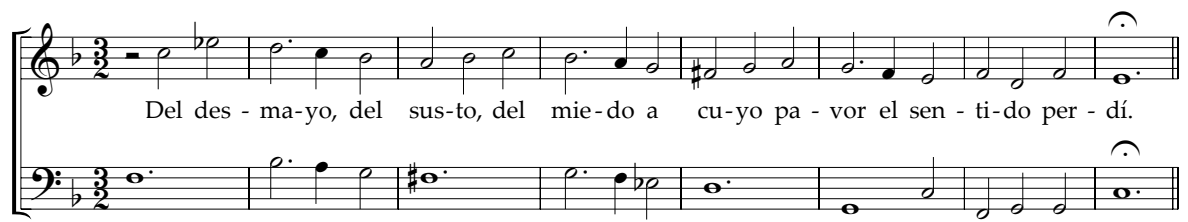


Mas no le valdrá, p[ues] vi

que, al ver esta admiración,

10.

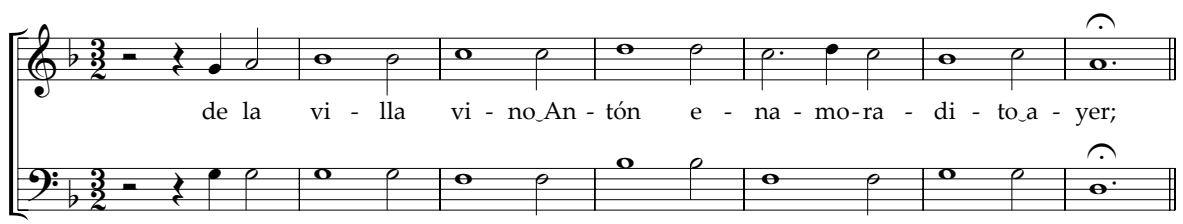

vino Gil y su mujer

los que fueron ahora y antes

11.

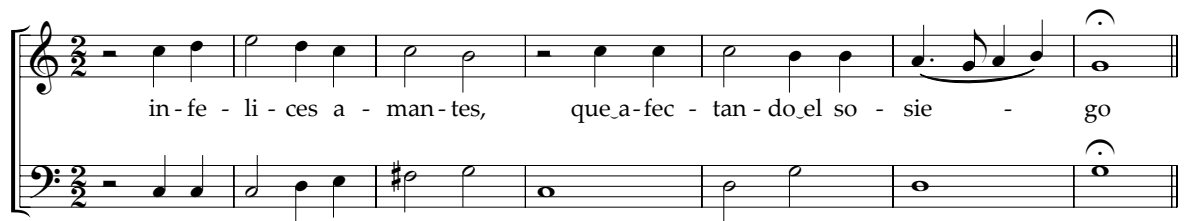

trujisteis en un talego

miel que tributa en panales.

12.

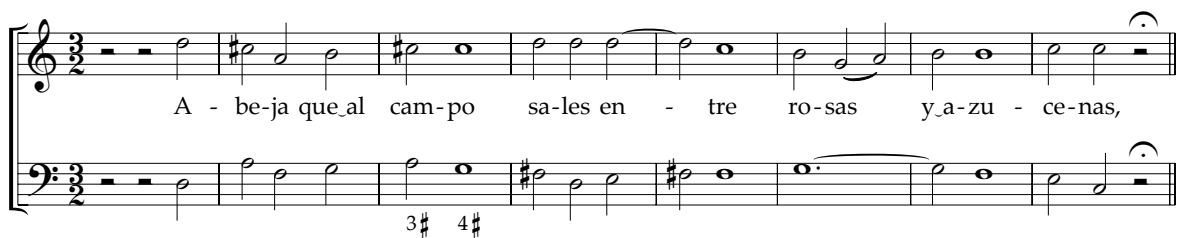

libando en dulces colmenas

dices con gemido ardiente:

13.

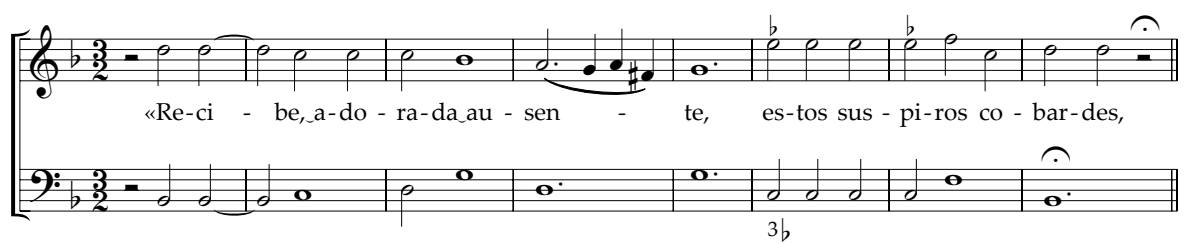

que antes de cincuenta tardes

dirán tres reyes de edad:

14.

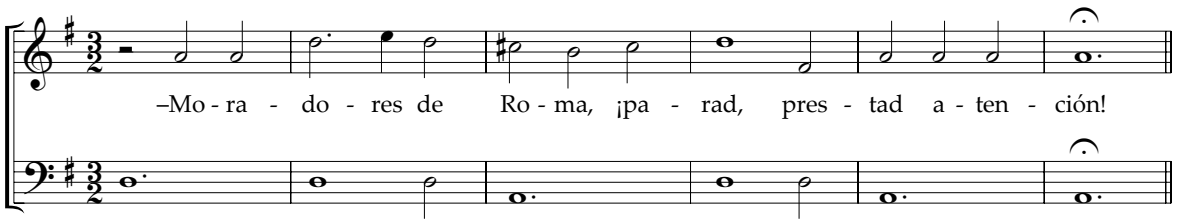


Y uno, por más devoción, trae su máscara de cisco».

15.

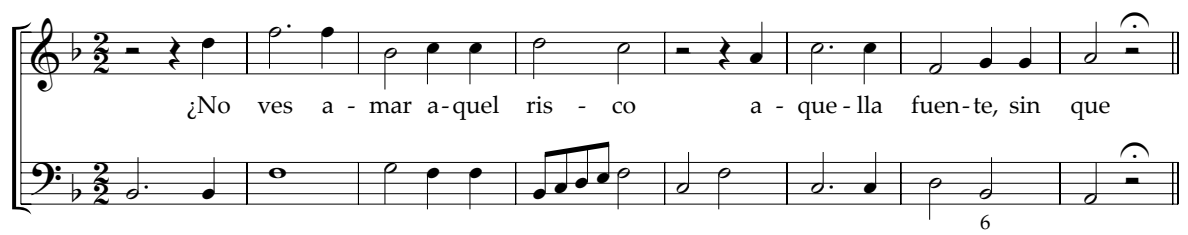

de su rendimiento en fe

embarga el ver tanta gente?

16.

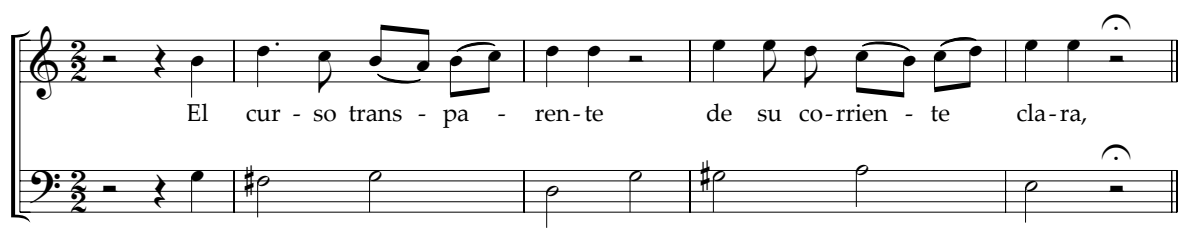

cuando al infante prepara

cogerle con sus infieles,

17.

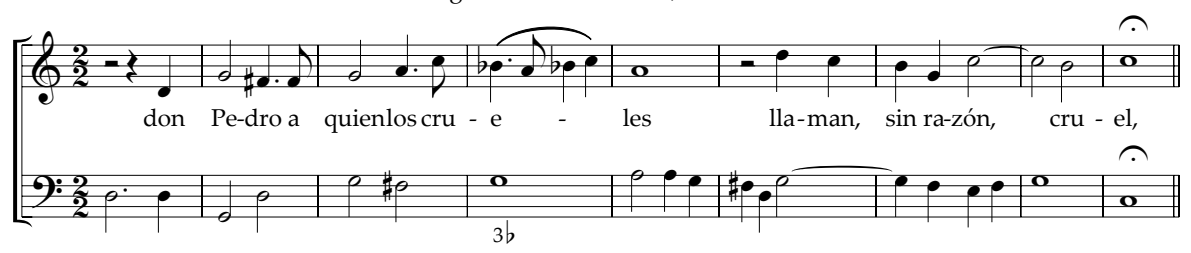

y en eso mienten, que él

excede en su Babilonia.

18.

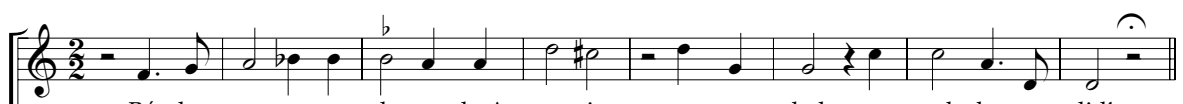

¡Bár-ba - ros mo-ra - do-res de_A - o-nia, sus-pen - ded, pa - rad, des-pe - did!

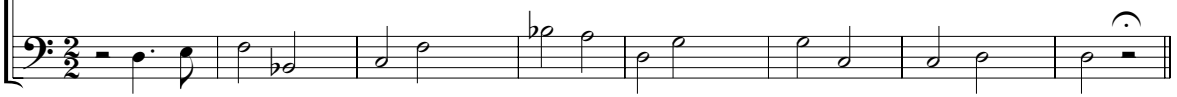

Mas no le valdrá el ardid,

aunque lo contrario dice.

19.

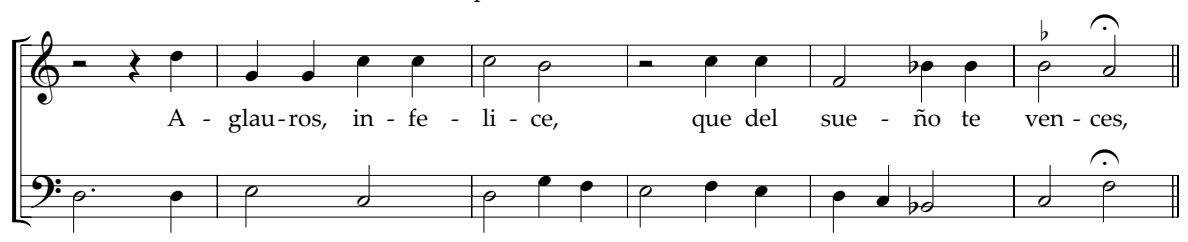


y aunque sepas más vascuences

que la tonada que fragua,
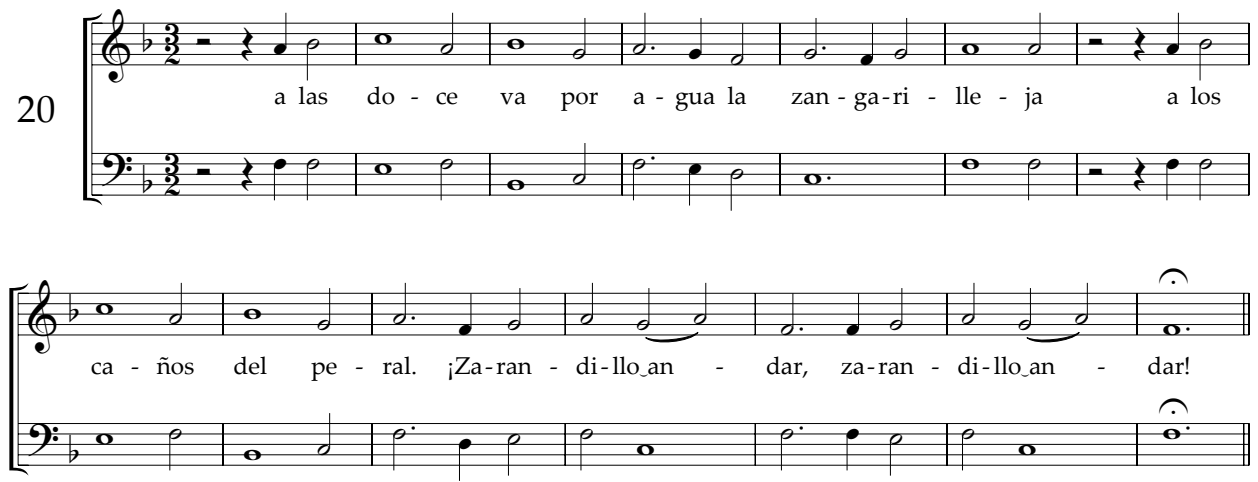

- Y acaba de par en par, musa que tonos escupe:
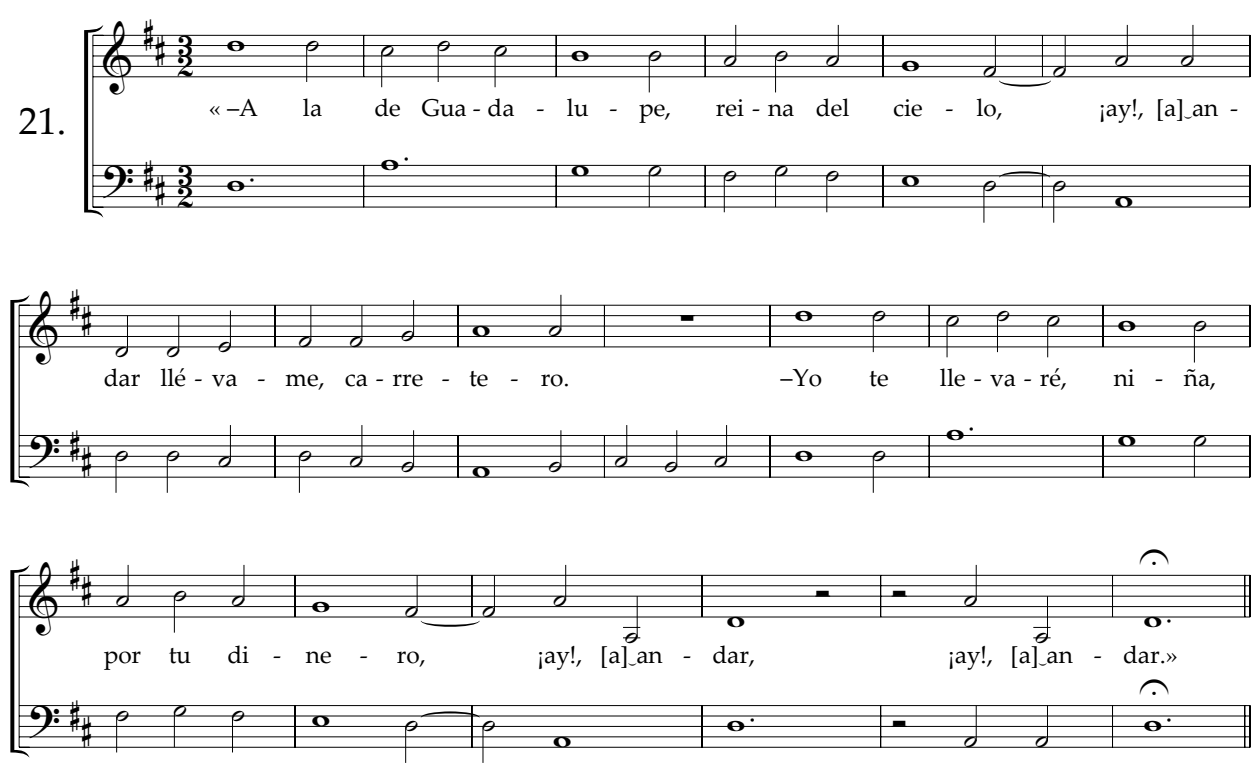
$x_{\text {acar }}$

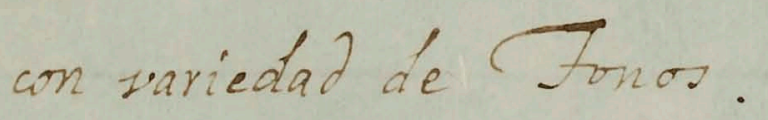

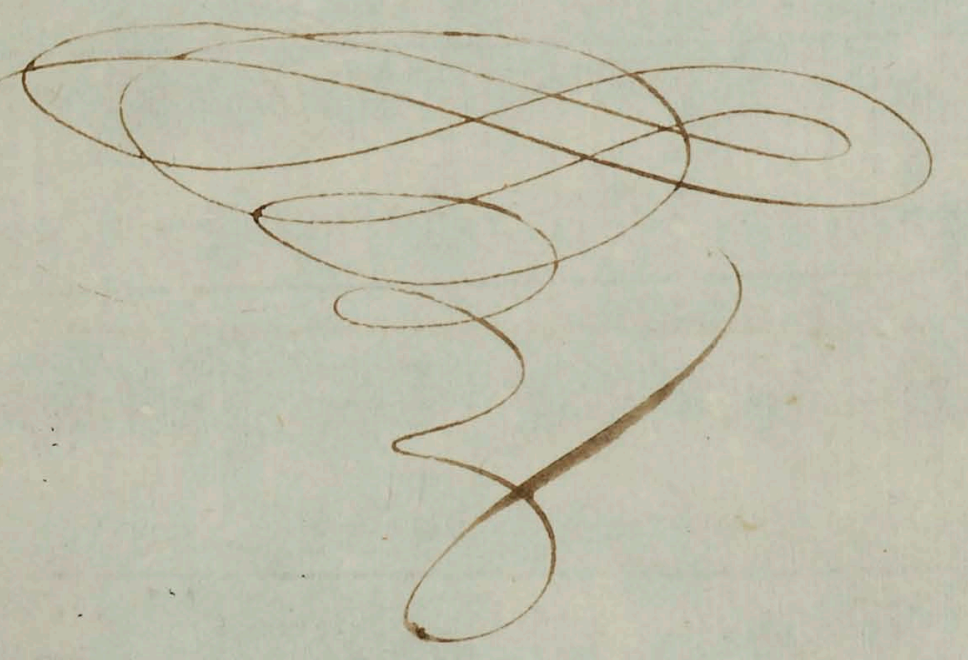


C. acara.

2

mastre salico - Gagar.

(72. Poeta con Licencía

we es menester ería caliai

parater vartreyen boeta.

Rurciáor de tres a the

con unapluma tixera

se hazer vestidos a metros

como coplas a baieta

Oy zia que cumple años

Aotia Iasqua aquella trejáa

celebrada fila ie Aoña

Pasidad te noche Guena.

- Merelando tovo. lo tono.

come simerclara yervas

oretendo nazer \& Las Muras

ina envalada burléca.

Q Qacarilla al Macimiento

ir campando con su extrella

atención por que en - ugar

de ena Gqua va allava ella.

Q Xacara dijo andresillo

aunque reá a troche y mocke

Ouitando a lá muerte el ceño

Uimbiar a lo. hombres quizo.

- As naciás por que halle.

ensu vilenicio orofundo.

(D),

crio Lara la mortal Cervíz.

ane labra nucrio pentura. texto. Eescogí para 9 . eftana

Le jiejre a. Demonio on Charco.

texto. Cn cada arroyo tributa sinser arrogo disino

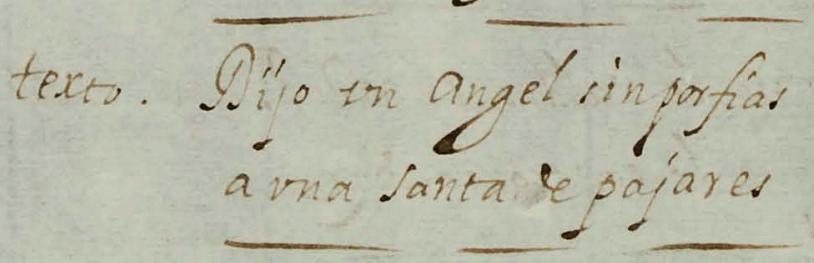

texto. Ue die a lo. pastores que en ereportal reposa.

terto. Jiende el Cenonío estar tramar Lesdic afomor apie queds.

texto. Ma. no levaldra om ó auc al ver esta admiración.

texto. Irno it y. Mu Muger.

$\rightarrow$ que fueron arayanter.

texto. Frugisteys en von tarego Mié que tríouta enpanares.

texts. Tisando en Julees ofmenas dizer con qenido ardente.

texto. Oue anter de cinquenta tardes

diran tres reyer \& edad.

texts. Luno pormas teuscion trae su Mascara de Liso.

texto. Desu rentimiento ex fee embarga elver tanta gente 


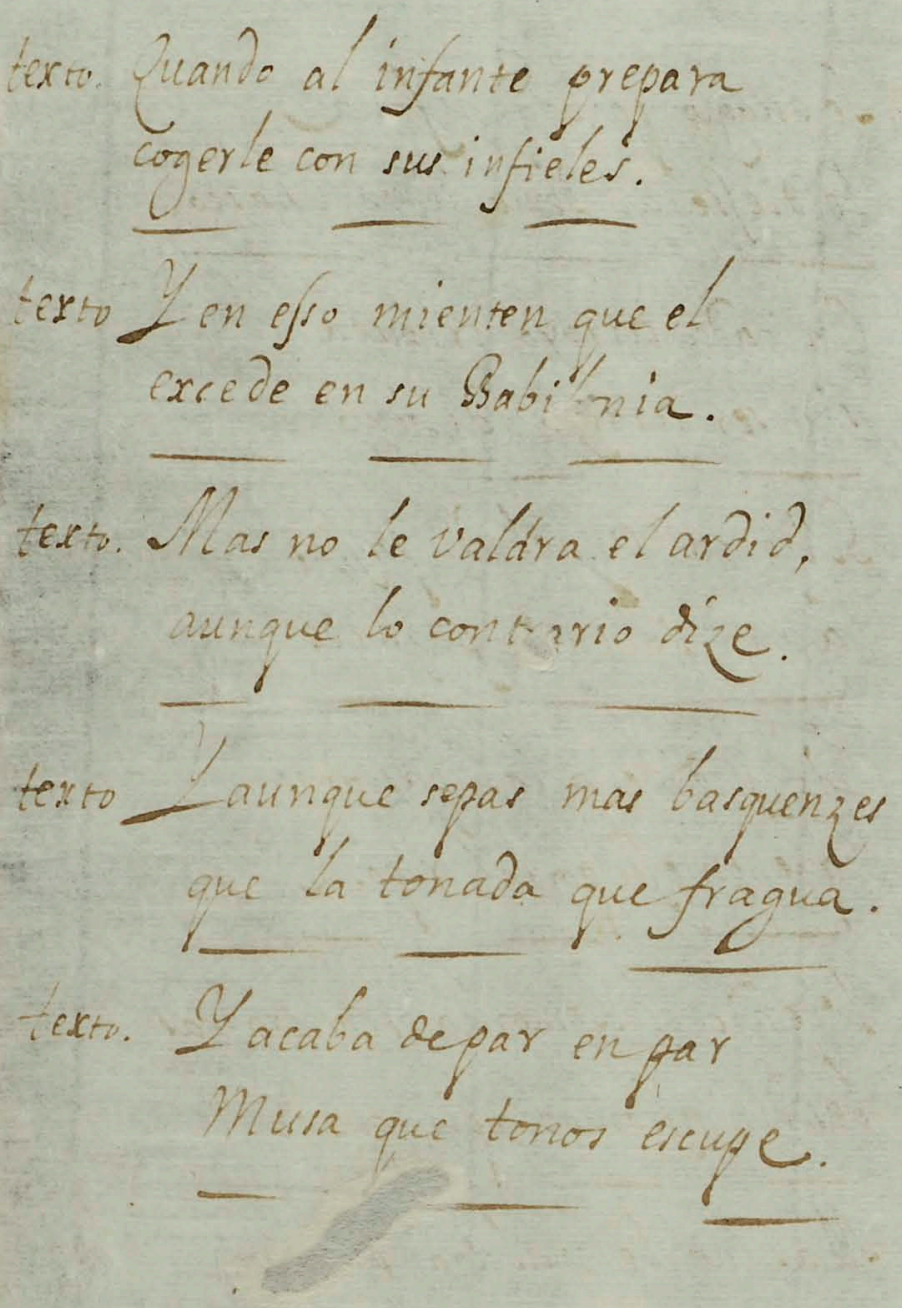




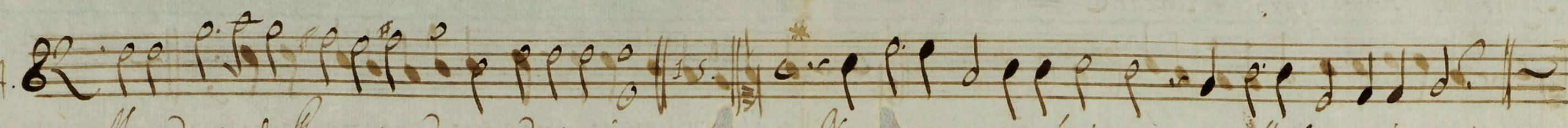

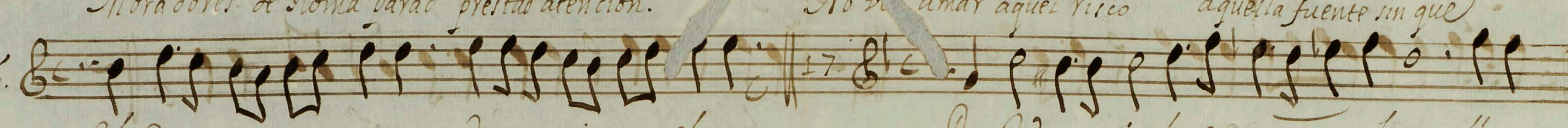

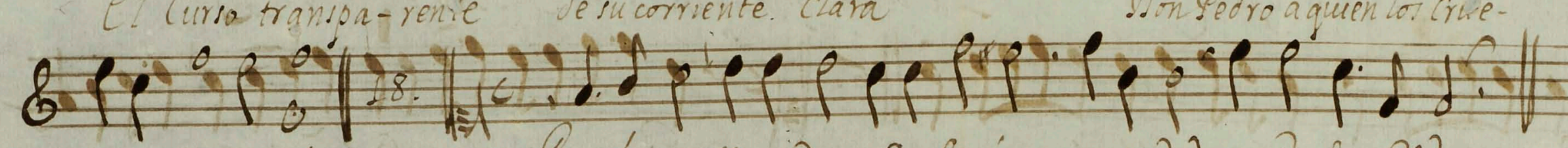

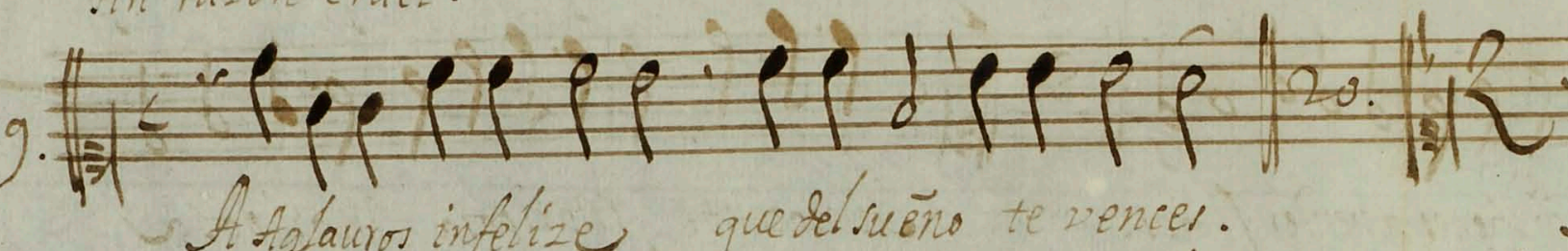

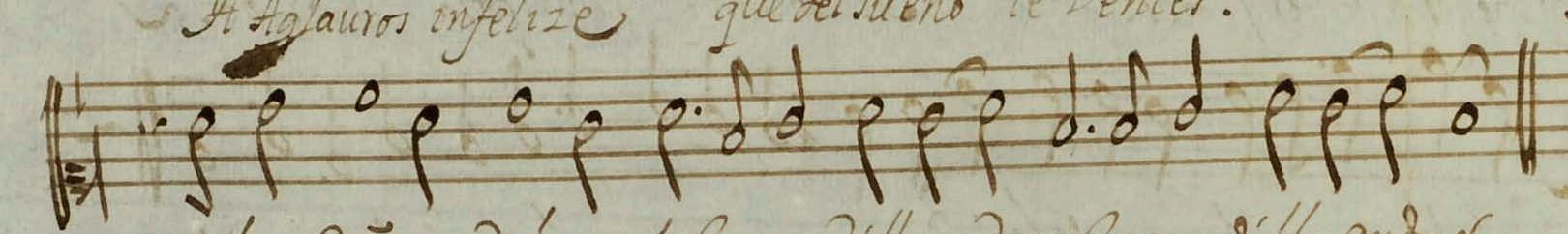

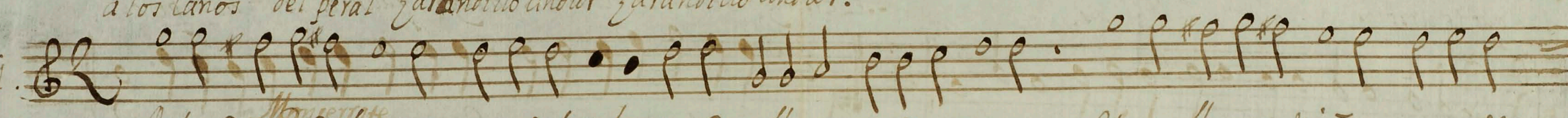

$8 \cdots(1)+13042$ 